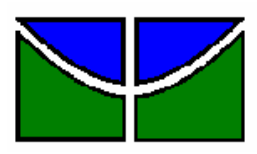

UNIVERSIDADE DE BRASÍLIA

FACULDADE DE ECONOMIA, ADMINISTRAÇÃO, CONTABILIDADE E CIÊNCIAS

DA INFORMAÇÃO E DOCUMENTAÇÃO

DEPARTAMENTO DE ADMINISTRAÇÃO

HÉLIO WILSON DE JESUS FERREIRA

\title{
LICENCIAMENTO AMBIENTAL - ESTUDO DE CASO SOBRE A ATIVIDADE LAVA-JATO NA CIDADE DE IMPERATRIZ - MA
}




\title{
HÉLIO WILSON DE JESUS FERREIRA
}

\section{LICENCIAMENTO AMBIENTAL - ESTUDO DE CASO SOBRE A ATIVIDADE LAVA-JATO NA CIDADE DE IMPERATRIZ - MA}

\author{
Monografia apresentada ao Departamento de \\ Administração como requisito para a obtenção do \\ título de Bacharel em Administração, na \\ modalidade à distância, pela Universidade de \\ Brasília-UnB.
}

Orientadora: MsC. Maria Neuza da Silva Oliveira 
Ferreira, Hélio Wilson de Jesus.

Licenciamento ambiental - estudo de caso sobre a atividade lava-jato na cidade de Imperatriz - MA / Hélio Wilson de Jesus Ferreira. - Brasília, 2010. 54 f.: il.

Monografia (bacharelado) - Universidade de Brasília, Departamento de Administração - EaD, 2010.

Orientadora: Profä. Msc. Maria Neuza da Silva Oliveira, Departamento de Administração.

1. Licenciamento Ambiental. 2.Direito Ambiental. 3. Meio Ambiente. Atividade de Lava-Jato.I. Título. 


\section{HÉLIO WILSON DE JESUS FERREIRA}

\section{LICENCIAMENTO AMBIENTAL - ESTUDO DE CASO SOBRE A ATIVIDADE LAVA-JATO NA CIDADE DE IMPERATRIZ - MA}

A Comissão Examinadora, abaixo identificada, aprova o Trabalho de Conclusão do Curso de Administração da Universidade de Brasília do (a) aluno (a)

Hélio Wilson de Jesus Ferreira

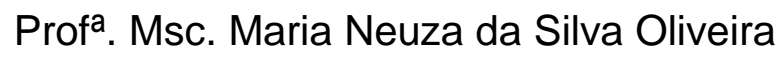
Professor-Orientador

Prof ${ }^{a}$ Msc. Mariana Marliere Létti

Professor-Examinador 
Dedico esse trabalho a toda minha família que sempre me deu estímulo para que eu continuasse em busca de uma vida mais confortável e prazerosa. 


\section{AGRADECIMENTOS}

Concluída uma Jornada diária de quatro anos, em que tive oportunidade de vivenciar grandes momentos de alegria e difíceis.

Agradeço em primeiro lugar a Deus, pelo dom da vida, e por me proporcionar a vitórias nas lutas da vida.

Aos meus pais, José Gomes Ferreira e Dalvina de Jesus Ferreira, pelo exemplo de luta e moral, e educação que me proporcionaram. Amo vocês eternamente!

Aos meus queridos irmãos, Dilma Ferreira e Silva, Dineide de Jesus Ferreira e Ronaldo de Jesus Ferreira por existirem em minha vida, pelo amor, apoio e incentivo, dispensados a mim.

Aos meus familiares e amigos, pela força e pela vibração em relação a esta jornada.

A coordenação da Universidade de Brasília e da Faculdade de Economia, Administração, Contabilidade e Ciências da Informação e Documentação, a todos muito obrigado. 
A força única no homem de manipular as coisas e acumular experiência the possibilitou quebrar as barreiras da temperatura, aridez, espaço, mares e montanhas, que sempre restringiram outras espécies a habitais específicos, com pouca variação. A mudança cultural substituiu, pela primeira vez, a evolução biológica, como meio de adaptação de um organismo a novos habitatos, terminando por incluir todos os espaços do planeta. 


\section{RESUMO}

Objetivou-se com esse trabalho diagnosticar a situação legal no que concerne o Licenciamento Ambiental na cidade de Imperatriz-Ma, na atividade Lava-Jato. O Licenciamento Ambiental é um instrumento da Política Nacional de Meio Ambiental, podendo ser entendido como sendo um instrumento coercitivo e preventivo de atividades potencialmente danosas ao meio ambiente. A pesquisa analisa e traz em diagnóstico uma fotografia atual - sob o ponto de vista legal e socioambiental - da atividade pesquisada. O estudo abordou um dos temas mais relevantes da atualidade, que é o meio ambiente. $O$ trabalho procurou verificar a situação da atividade lava-jato na cidade de Imperatriz, com relação ao licenciamento ambiental, de forma que se levantasse dados do seu potencial poluidor, sua ocupação adequada além de sua condição no que se refere à normalidade das leis vigentes. Concluiu-se que existe um aspecto relevante na abordagem no que diz respeito ao uso indiscriminado da principal matéria prima dessa atividade Lava-jato, qual seja, a água.

Palavras-chave: Licenciamento Ambiental. Atividade de Lava-Jato. Direito Ambiental. Meio Ambiente. 


\begin{abstract}
This paper aims to diagnose the legal actual status concerning the activity of car washing in Imperatriz city in the state of Maranhão. What chemical products are used and how they are observed by the government.

Understanding environmental licence as an instrument of prevention for potencial harmful to the environment, the paper analyses and diagnoses in an update portrait concerning legal and socio-environmental - of the researched activity. The paper also approaches two of the utmost themes in the present: Law applying and the Environment. It is not approached in this paper the so-called green car washing common in bigger cities, but far from the small cities realities. This paper reveals important aspects as far as indiscriminated use of this which is the main raw material in the activitiy of car washing, the water.
\end{abstract}

Keywords: Environmental licensing. Environmental right. Environment. Car washing 


\section{LISTA DE GRÁFICOS}

Gráfico 1 - Escolaridade do proprietário ................................................. 39

Gráfico 2 - Qual o tempo de atuação ......................................................... 40

Gráfico 2 - Há Licença ambiental para exercer essa atividade? .......................... 41

Gráfico 4 - Há tratamento de efluente conforme estabelece a Legislação vigente no nosso País? .......................................................... 42

Gráfico 5 - Há controle sobre a quantidade de água utilizada? .......................... 43

Gráfico 6 - Que produtos são utilizados na lavagem dos automóveis? ................. 44

Gráfico 7 - Você respeita as normas estabelecidas pela legislação ambiental referente ao funcionamento dos lava jatos? 45

Gráfico 8 - Os funcionários usam equipamentos de proteção individual EPI's quando estão no exercício da sua função? 46 


\section{SUMÁRIO}

LISTA DE GRÁFICOS

1 INTRODUÇÃO

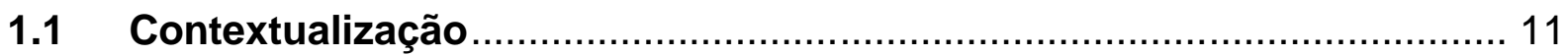

1.2 Formulação do Problema ................................................................... 13

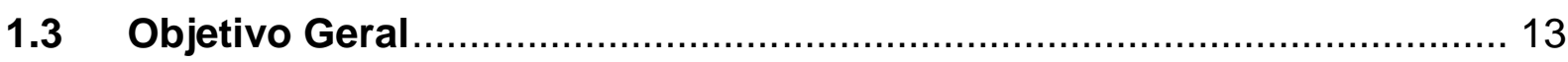

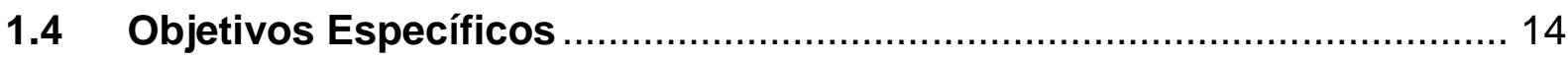

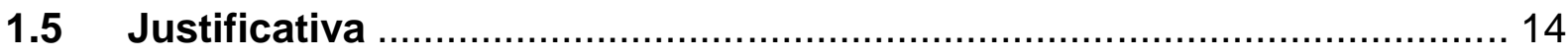

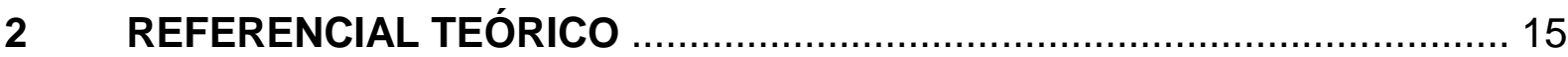

2.1 Algumas considerações acerca do direito e meio ambiente .................. 15

2.2 Contexto histórico do Licenciamento Ambiental .................................. 17

2.3 Empreendimentos que necessitam do licenciamento ambiental ........... 19

2.4 Algumas considerações sobre Licenciamento Ambiental ...................... 20

2.5 Classificação de licença ambiental e procedimento do licenciamento ... 22

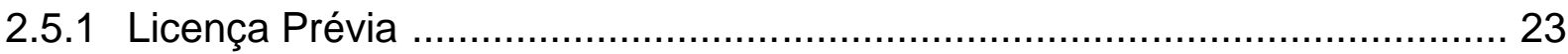

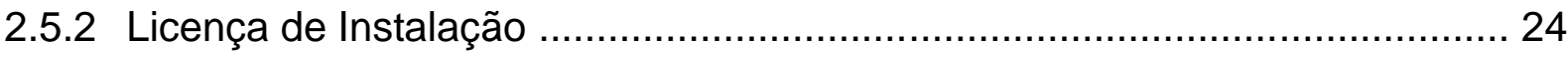

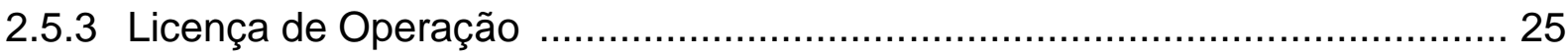

2.5.4 Procedimentos para a obtenção da licença ambiental .............................. 26

2.6 Normas e padrões de qualidade de água na lavagem de veículos ......... 27

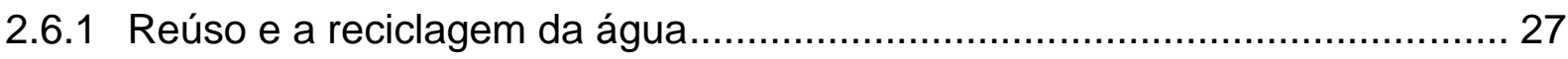



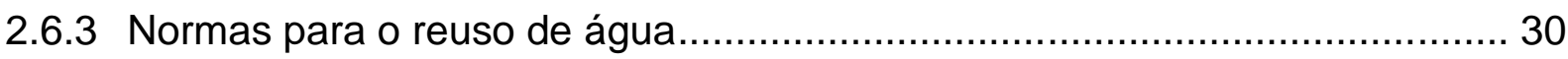

2.6.4 A qualidade da água a ser reciclada na lavagem de veículos....................... 27

2.7 Efluentes na lavagem de veículos .................................................. 32

2.7.1 Características de efluentes gerados na lavagem de veículos .................... 32

2.7.2 Descrição dos tipos de lavagem de veículos …….................................... 33

2.7.3 Benefícios e problemas da reciclagem de efluentes na lavagem de veículos 35

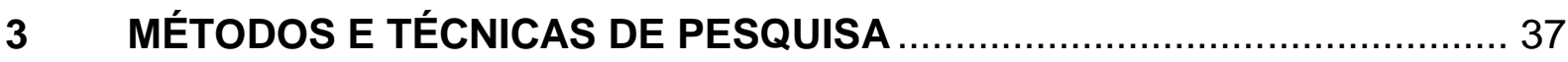

3.1 Tipo e descrição geral da pesquisa .................................................... 37

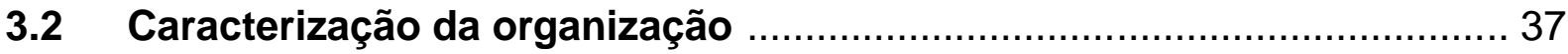

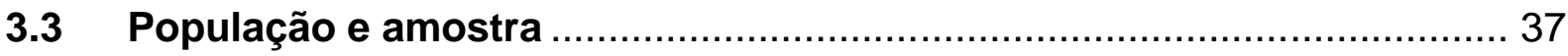

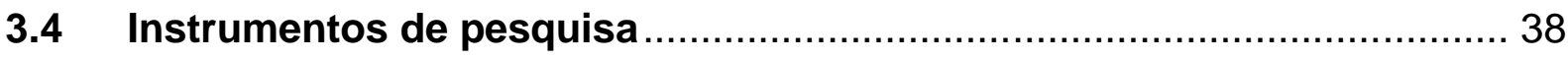


3.5 Procedimentos de coleta e de análise de dados ............................... 38

4 ANALISE E INTERPRETAÇÃO DOS RESULTADOS .............................. 38

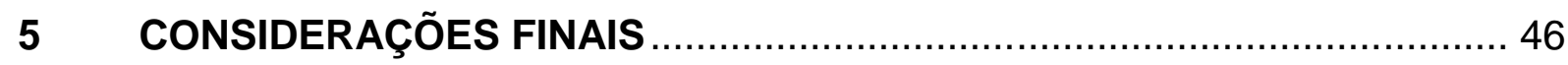

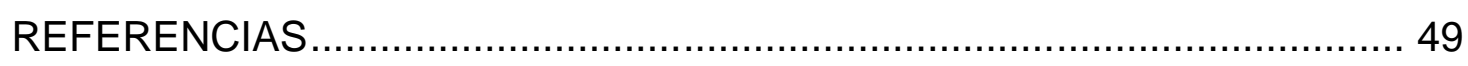

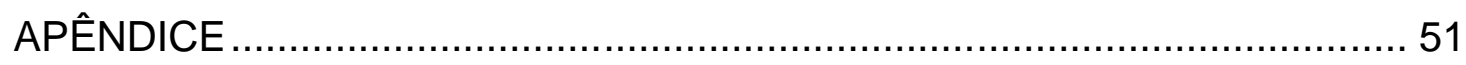

Apêndice A - Questionário de coleta de dados da pesquisa de campo ........50 50 


\section{INTRODUÇÃO}

\subsection{Contextualização}

O tema meio ambiente tem, nas últimas décadas, sido um dos principais assuntos na agenda de todos os governos e ocupado a pauta de decisões de grandes empresas no mundo. A partir de um sentimento latente - ainda nos idos de 70, por ocasião da Conferência de Estocolmo (Estocolmo, 1972), numa forma encarada como puramente ideológica -, rumo a uma patente preocupação global, responsabilidade socioambiental, hoje em dia, não é voga. Trata-se de questão que, sem margem para o exagero, é vital para o ser humano. Colocar de onde retirou as informações ok

Nenhum governo hoje quer pagar o preço de ser visto como poluidor. Nenhuma grande empresa da atualidade quer acumular passivos ambientais que podem levá-la, em muitos casos, à bancarrota. Pelo contrário: A correta postura no que diz respeito ao meio ambiente pode, na verdade, ser convertida em um ativo intangível de valor incalculável.

No Brasil, ainda em 1981, a lei nº. 6938, que institui instrumentos como 0 Eia (Estudo prévio de Impacto Ambiental) e Rima (Relatório de Impacto Ambiental) dão o tom do controle de atividades potencialmente danosas ao meio ambiente.

Nesse contexto, o licenciamento ambiental apresenta-se como dos instrumentos da gestão ambiental de caráter coercitivo, tipicamente de comando e controle, por ter caráter autorizativo, condicionando a construção, instalação e funcionamento de determinadas obras e atividades ao cumprimento de exigências e medidas mitigadoras e de controle ambiental por parte dos empreendedores, previstos na Política Nacional de Meio Ambiente - PNMA, estabelecido pela lei nº․ 6938 de 1981.

Porém, esta ferramenta tem a finalidade de prevenção, buscando promover o controle prévio à construção, instalação, ampliação e funcionamento de estabelecimentos e atividades que utilizadores de recursos ambientais, 
considerados efetiva e potencialmente poluidores, bem como os capazes, sob qualquer forma, de causar degradação ambiental.

O Licenciamento Ambiental já vinha sendo utilizado no Brasil em alguns Estados da Federação, desde a década de 70, mas em nível federal só passou a ser utilizado em 1981, quando foi regulamentado pelos Decretos $\mathrm{n}$ ㅇ. 88351/83 e 99.274/90. Logo foi estabelecida uma série de resoluções do Conselho Nacional de Meio Ambiente-CONAMA e outros dispositivos legais, que formaram os procedimentos gerais e específicos para o licenciamento ambiental de determinadas atividades.

Deve-se frisar que a Carta Magna de 1988, que é posterior à lei no . 6938/81, reza em seu artigo 225, inciso IV, que se deve "exigir, na forma da lei, para instalação de obra ou atividade potencialmente causadora de significativa degradação do meio ambiente, estudo prévio de impacto ambiental, a que se dará publicidade". Ou seja, as referidas obras do artigo supra, devem ser precedidas de Estudo Prévio de Impacto Ambiental-EIA. No entanto, a Constituição de 1988 não cita no referido artigo o licenciamento ambiental.

Em 1991, no entanto, através da resolução 237 estabelecida pelo Conselho Nacional do Meio Ambiente - CONAMA, há um afrouxamento no tratamento legal de atividades danosas ao meio ambiente. É nessa resolução, em seu artigo $12 \S 1^{\circ}$, que está previsto processo simplificado para atividades e empreendimentos de pequeno potencial de impacto ambiental.

Diante disso, apresenta-se um mundo cada vez mais voltado ao consumo, alimentado pelo crescimento econômico e pelo desenvolvimentismo. No Brasil, onde o crescimento tem apresentado sucessivos incrementos nos últimos anos, fica claro os efeitos desse cenário. A frota nacional de veículos, impulsionada pelo aumento do poder aquisitivo do brasileiro, e por uma política econômica expansionista - sem falar de medidas anticíclicas adotadas como atenuante aos efeitos da chamada crise do crédito - não só foi renovada como aumentou de forma notória o número de carros nas ruas.

Mais carros nas ruas, mais emissões e mais se percebe um fenômeno comum em países desenvolvidos. O típico cidadão possuidor de um veículo que, aos domingos, estacionava seu carro na frente de sua casa e tranquilamente o 
lavava deu lugar àquela pessoa que - tão escasso de tempo e sobrecarregado de afazeres - terceiriza essa atividade para uma empresa especializada.

É nesse contexto que este documento, através de pesquisa exploratória, se propõe a averiguar como se dá o controle da atividade lava-jato numa cidade de médio porte. A cidade escolhida foi Imperatriz, localizada no sudoeste do estado do Maranhão.

\subsection{Formulação do Problema}

O problema analisado nesta pesquisa é a situação legal de licenciamento ambiental no que diz respeito à atividade de lava-jato na cidade de Imperatriz - Ma. Tais problemáticas são as questões de captação de água, tipos e quantidades de produtos químicos utilizados, manutenção de caixas separadoras, quando houver, entre outros. Diante disso, questiona-se se os órgãos responsáveis pela aplicação e fiscalização das normas regulamentadoras desse tipo de atividade têm cumprido seu papel para que esse tipo de atividade seja devidamente fiscalizado.

\subsection{Objetivo Geral}

Analisar a situação da atividade lava-jato na cidade de Imperatriz, com relação ao licenciamento ambiental, de forma que se levante dados de controle legal, sua ocupação adequada além de sua condição no que se refere à normalidade das leis vigentes. 


\subsection{Objetivos Específicos}

Especificamente, objetivou-se diagnosticar a situação legal da atividade sob o aspecto ambiental; verificar a aplicação de normas e fiscalização dos órgãos competentes em relação à atividade de lava-jato na cidade de Imperatriz-MA; identificar o índice de tratamento e a quantidade de água utilizada na lavagem de veículos.

\subsection{Justificativa}

Justifica-se este trabalho com base num significativo aumento da consciência ambiental e das leis específicas sobre geração de resíduos provenientes da atividade industrial - o que causou inquestionável melhoria quanto à vigilância e responsabilidade sobre a questão da disposição final de resíduos. Entretanto, pequenos empreendimentos ainda trabalham de forma tecnologicamente simplificada, exercendo suas funções de forma agressiva ao meio ambiente. Um exemplo é o popular lava - jato, foco da pesquisa em estudo.

Foi identificado através da pesquisa de campo realizada por meio de questionário de coleta de dados que na cidade de Imperatriz - MA existe uma parcela de estabelecimentos desse tipo que utilizam de forma descontrolada e insegura produtos químicos de alto poder de intoxicação e contaminação gerando, ao fim de sua utilização, uma lama impregnada com os resíduos químicos que, invariavelmente, contaminarão rios, riachos e até o lençol freático. Adicione a isso um uso descomedido dos recursos hídricos.

Justifica-se este trabalho com base num significativo aumento da consciência ambiental e das leis específicas sobre geração de resíduos provenientes da atividade industrial - o que causou inquestionável melhoria quanto à vigilância e responsabilidade sobre a questão da disposição final de resíduos. Entretanto, pequenos empreendimentos ainda trabalham de forma tecnologicamente 
simplificada, exercendo suas funções de forma agressiva ao meio ambiente. Um exemplo é o popular lava - jato, foco da pesquisa em estudo.

É sabido da grande incidência de informalidade na economia brasileira. Também é expressivo o número de pequenas empresas. Empreendimentos informais ou pequenos, pela sua natural possibilidade de capilarização, por vezes, trabalham à margem da rigidez de controle ambiental experimentado por grandes corporações. A atividade de lavagem de veículos tem como principal insumo a água, cada vez mais escassa no mundo. Além disso, há resíduo químico proveniente da atividade. Um olhar minimamente crítico e fundamentalmente empírico é fator desencadeante para uma série de questionamentos socioambientais de relevância inquestionável dado o momento em que vivemos.

Desta forma, esta pesquisa encontra relevância no fato de apresentar um estudo de caso sobre uma atividade comum em grandes, médias e pequenas cidades e que causa seus impactos negativos ao meio ambiente. Uma outra justificativa para a importância da pesquisa é que ela trata de um recurso que é a base da existência de vida na terra - a água, e que sua utilização irracional constitui crime moral para com o meio.

\section{REFERENCIAL TEÓRICO}

\subsection{Algumas considerações acerca do direito e meio ambiente}

O direito a um meio ambiente ecologicamente harmonioso é garantia constitucional, previsto na Carta Magna de 1988 em seu artigo 225, que reza que

"[...] todos têm direito a um meio ambiente ecologicamente equilibrado, de uso comum do povo e essencial à sadia qualidade de vida, impondo-se ao Poder Público e à coletividade o dever de defendê-lo e preservá-lo para os presentes e futuras gerações." (BRASIL, 1988).

Não se trata, portanto, de simples faculdade do poder público, mas de um dever constitucional do Estado de cuidar para que qualquer ação humana que 
resulte em dano ambiental seja fiscalizada e combatida, evitando assim os impactos ambientais, constantes nos dias atuais. Porém, há impacto ambiental toda vez que a ação de fatores externos causados essencialmente pelo homem são alterados de forma negativa ao meio ambiente.

Nesse sentido, o conceito de impacto ambiental é definido pela resolução do Conselho Nacional do Meio Ambiente - CONAMA, №. 001/86, como qualquer alteração das propriedades físicas, químicas e biológicas do meio ambiente, causada por qualquer forma de matéria ou energia resultante das atividades humanas que direta ou indiretamente afetam a saúde, a segurança e o bem-estar da população, as atividades sociais e econômicas, a biota, as condições estéticas e sanitárias do meio ambiente e a qualidade dos recursos ambientais.

O conceito de impacto ambiental abrange apenas os efeitos da ação humana sobre o meio ambiente, isto é, não considera os efeitos oriundos de fenômeno naturais, e ainda dá ênfase principalmente aos efeitos destes impactos no homem, demonstrando uma conotação antropocêntrica dessa definição (CONAMA, 1992).

A lei federal 6.938 de 31 de agosto de 1981, lei da Política Nacional do Meio Ambiente, recepcionada pela Constituição Federal - CF de 1988 inclui em seu artigo 9o inciso IV o licenciamento e a revisão das atividades efetiva ou potencialmente poluidoras do meio ambiente dentre seus instrumentos. Essa mesma lei em seu artigo 10 determinou que a construção, instalação, ampliação e funcionamento de estabelecimentos e atividades utilizadoras de recursos ambientais, considerados efetiva e potencialmente poluidores, bem como capazes, sob qualquer forma, de causar degradação ambiental, dependerão de prévio licenciamento do órgão estadual competente, integrante do Sistema Nacional do Meio Ambiente - SISNAMA, e do Instituto Nacional do Meio Ambiente e Recursos Naturais Renováveis - IBAMA, em caráter supletivo, sem prejuízo de outras licenças exigíveis. Nesse sentido, configura como um dos principais instrumentos normativos que cuida do licenciamento ambiental (BRASIL, lei no 6.938/81). 


\subsection{Contexto histórico do Licenciamento Ambiental}

O termo meio ambiente foi usado pela primeira vez na década de 1960 , em Roma, com a finalidade de reconstrução dos países no pós-guerra. Neste momento histórico foi estabelecida a polêmica sobre os problemas ambientais, até então entendido como um mal necessário, devido ao desenvolvimento decorrente da revolução industrial (BAPTISTA, 1998).

Deve-se frisar que a primeira manifestação institucionalizada de política relacionada ao impacto ao meio ambiente surgiu com a criação do National Environmental Policy Act-NEPA no ano de 1969, nos Estados Unidos da América, desenvolvendo, no ano seguinte, o processo de Avaliação de Impacto Ambiental AIA, como ferramenta de política ambiental (MACHADO, 2005).

É importante citar que tal ferramenta dispunha sobre os objetivos e princípios da política ambiental norte-americana, exigido para todos os empreendimentos de potencial impacto, com observação dos determinados pontos: identificação dos impactos ambientais; efeitos ambientais negativos da proposta; alternativas da ação; relação dos recursos ambientais negativos no curto prazo e a manutenção ou mesmo melhoria do seu padrão no longo prazo.

No ano de 1972, na cidade de Estocolmo, na Suécia, foi realizada a I Conferência Mundial de Meio Ambiente cuja principal finalidade foi estabelecer uma visão global e princípios comuns, que serviriam de inspiração e orientação para a humanidade na preservação e melhoria do ambiente. Tal proposta resultou na Declaração sobre o Ambiente Humano (MACHADO, 2005).

É de suma importância afirmar que a Conferência de Estocolmo representou um marco que mudou de patamar a preocupação com as questões ambientais e passou a fazer parte das políticas de desenvolvimento adotadas nos países mais avançados e nos países em processo de desenvolvimento (BARBIERI, 1998).

A Avaliação de Impactos Ambientais se tornou o instrumento mais discutido daquela época até os dias atuais. $E$ houve um grande avanço no tratamento das questões ambientais, tanto no tocante ao aprimoramento da 
legislação ambiental quanto à conscientização da população (SALGADO; PALHARES, 1993).

Destaca-se que no Brasil, as primeiras tentativas de aplicação de métodos para análise de impactos ambientais surgiram devido às exigências de órgãos financeiros internacionais para aprovação de empréstimos a projetos governamentais. A adoção de práticas adequadas de gerenciamento ambiental em quaisquer atividades modificadoras do meio ambiente tornou-se cada vez mais necessário devido a crescente conscientização da sociedade (MILARÉ; BENJAMIN, 1993).

As questões de desenvolvimento de práticas sociais - como a conscientização da sociedade - levaram o governo brasileiro a sancionar, em 1981, a Lei ํ․ 6.938 que estabelece a Política Nacional do Meio Ambiente e criou o Sistema Nacional do Meio Ambiente - SISNAMA, amparando fundamentos para a proteção ambiental no país, os quais vêm sendo regulamentados por meio de decretos, resoluções, normas e portarias dos Conselhos Nacional, Estaduais e Municipais (BRASIL, lei oㅜ 6.938/81).

Dentre essas prerrogativas, foi criado dentre outros instrumentos, o "Licenciamento Ambiental", que se constitui, portanto, em um dos instrumentos da Política Nacional do Meio Ambiente e tem como finalidade promover o controle prévio à construção, instalação, ampliação e funcionamento de estabelecimentos e atividades utilizadoras de recursos ambientais, considerados efetiva e potencialmente poluidores, bem como os capazes, sob qualquer forma, de causar degradação ambiental (SALGADO; PALHARES, 1993).

Tais instrumentos foram inicialmente aplicados às indústrias de transformação. O Licenciamento Ambiental passou então a abranger uma gama de projetos de infra-estrutura promovidos por empresas e organismos governamentais, estendendo-se ainda às indústrias extrativas e aos projetos de expansão urbana, agropecuária e turismo, cuja implantação possa, efetiva ou potencialmente, causar degradação ambiental (IBAMA, 2002).

Observa-se que ao se exigir 0 Licenciamento Ambiental para determinadas atividades, busca-se estabelecer mecanismos de controle ambiental nas intervenções setoriais, os quais foram reforçando a Política Nacional do Meio Ambiente. Os mecanismos estabelecidos pela lei no. 9.605, de 12 de fevereiro de 
1998, que dispõe sobre as sanções penais e administrativas lesivas ao meio ambiente, em seu artigo 60, estabelecem a obrigatoriedade do licenciamento ambiental das atividades degradadoras da qualidade ambiental, contendo, inclusive, as penalidades a serem aplicadas ao infrator (OLIVEIRA, 1997).

\subsection{Empreendimentos que necessitam do Licenciamento Ambiental}

A constituição Federal de 1988 não determina obrigatoriedade de licenças ambientais para todo e qualquer empreendimento. A Lei 6.938 de 1981 estabeleceu a necessidade de licenciamento apenas para as atividades utilizadoras de recursos ambientais, consideradas poluidoras do meio ambiente e capazes de causar degradação ambiental.

A legislação supracitada deixa claro quais as características dos empreendimentos que necessitam de Licenciamento Ambiental, quais sejam, apenas aquelas atividades que se servem de recursos ambientais poluidores do meio ambiente, potenciais causadores de danos ambientais

Porém, ao analisar os conceitos de poluição e degradação observa-se a abertura para a interpretação da norma legal de determinação da necessidade, ou não de licenciamento. A definição legal do termo poluição é a degradação da qualidade ambiental resultante de atividades humanas. O termo degradação é traduzido pela legislação como a alteração adversa das características do meio ambiente. Considerando que não há como fixar de forma definitiva as atividades que causam degradação ou mesmo o grau de alteração adversa, caberá consulta ao órgão ambiental para determinar se o empreendimento necessita de licenciamento.

No entanto, observa-se que existem atividades que, conforme a legislação vigente, já deixa clara a necessidade do licenciamento. Desse modo a resolução do CONAMA de ํo. 237/97 traz em seu texto uma relação de atividades sujeitas ao licenciamento ambiental. Tal relação é exemplificativa e não pretende esgotar todas as possibilidades. Tal empreendimento seria impossível, além de inútil. Mas funciona como norteador para os empreendedores. 
Pode ser observado que um dos fatores que fez com que aumentasse 0 interesse dos empreendedores em verificar a necessidade de licenciamento foi a possibilidade de incorrer nas penalidades previstas no artigo 60 da Lei ํ‥ 9.605/98 que estabeleceu os Crimes Ambientais, segundo o qual, diz o seguinte:

Construir, reformar, ampliar, instalar ou fazer funcionar, em qualquer parte do território nacional, estabelecimentos, obras ou serviços potencialmente poluidores sem licença ou autorização dos órgãos ambientais competentes, ou contrariando as normas legais e regulamentares pertinentes: Pena detenção, de um a seis meses, ou multa, ou ambas as penas cumulativamente.

\subsection{Algumas considerações sobre Licenciamento Ambiental}

O licenciamento ambiental configura ferramenta essencial para 0 desenvolvimento sustentável e para o combate a crimes ambientais. Não somente porque ordena o crescimento econômico, mas também porque evita prejuízos à sociedade, agindo, entre outras formas, prevenindo catástrofes industriais e poluição de corpos hídricos.

O Licenciamento Ambiental é uma obrigação legal prévia à instalação de qualquer empreendimento ou atividade potencialmente poluidora ou degradadora do meio ambiente além de ser um instrumento indispensável da gestão ambiental. (IBAMA 2002).

A Resolução CONAMA 237/97 define, licenciamento ambiental, em seu artigo primeiro, como: "procedimento administrativo pelo qual o órgão ambiental competente licencia a localização, instalação, ampliação e operação de empreendimentos e atividades utilizadoras de recursos ambientais, consideradas efetiva ou potencialmente poluidoras ou aquelas que, sob qualquer forma, possam causar degradação ambiental, considerando as disposições legais e regulamentares e as normas técnicas aplicáveis ao caso".

Configura, portanto, um ato administrativo fundamentado no princípio da prevenção, uma vez que é empregado para se evitar o dano ambiental. 
Somam três as espécies de licença ambiental, enumeradas no artigo $8^{\circ}$ da Resolução CONAMA 237/97: Licença Prévia; Licença de Instalação; e Licença de Operação.

A Licença Prévia é concedida na fase inicial, quando do planejamento do empreendimento ou atividade. Ela aprova a localização do empreendimento ou atividade efetiva ou potencialmente lesiva ao meio ambiente, atestando a viabilidade ambiental. Além disso, estabelece os requisitos básicos e condicionantes a serem atendidas nas próximas fases de implementação.

A Licença de Instalação viabiliza a instalação do empreendimento ou atividade em consonância às especificações constantes dos planos, programas e projetos aprovados. Devem incluir-se nestes, as medidas de controle ambientais e demais condicionantes.

Por fim, há a Licença de Operação, que possibilita o início do empreendimento ou atividade, o que ocorre após a verificação do efetivo cumprimento do que fora determinado quando da emissão das duas licenças anteriores, com as medidas de controle ambientais e condicionantes determinados para a operação.

Convém observar que a mesma Resolução CONAMA 237 de 19 de dezembro de 1997 estabelece em seu artigo 6o, que é competência ao governo municipal o licenciamento de empreendimentos e atividades causadoras de impactos ambientais locais e daquelas que Ihes forem delegadas pelo Estado. Para tanto, necessário se faz que o cidade possua organização administrativa.

É de fundamental importância frisar que a Constituição Federal postula, em seu artigo 24, que:

[..] compete à União aos Estados e ao Distrito Federal legislar concorrentemente sobre: a responsabilidade por danos ao meio ambiente, ao consumidor, a bens e direitos de valor artístico, estético, histórico, turístico e paisagístico local, educacional, cultural, de ensino e saúde de direito urbanístico local e outros. (BRASIL, 1988).

O Ministério Público passou a ter essencial papel na proteção do meio ambiente no Brasil com a Lei 6938/81, Lei da Política Nacional do Meio Ambiente PNAMA, que postula que: “... O Ministério Público da União e dos Estados terá legitimidade para propor ação de responsabilidade civil e criminal, por danos causados ao meio ambiente". 
Por fim, há a participação direta, salvaguarda pela Lei 7347/85, e a lei da Ação Civil Pública ou Lei dos Interesses Difusos - que ampliou a legitimidade para a propositura das ações para tutela dos chamados interesses difusos - incluindo aí o meio ambiente - dando igual poder às associações e outros órgãos públicos, além do próprio Ministério Público.

\subsection{Classificação de licença ambiental e procedimento do licenciamento}

A Licença Ambiental pode ser dispensável ou não, dependendo da atividade ou do empreendimento a ser desenvolvido. Neste capítulo frisa-se que cada etapa do processo de licenciamento ambiental exige um documento adequado, como no planejamento de um empreendimento ou de uma atividade, onde utiliza-se a Licença Prévia-LP. Já na construção de obras, deve ser utilizada a Licença de Instalação-LI, e na operação ou funcionamento, utiliza-se a Licença de Operação LO.

A definição de Licença Ambiental também está definida na Resolução CONAMA no. 237/97, a qual determina que:

É o ato administrativo pelo qual o órgão ambiental competente, estabelece as condições, restrições e medidas de controle ambiental que deverão ser obedecidas pelo empreendedor, pessoa física ou jurídica, para localizar, instalar, ampliar e operar empreendimentos ou atividades utilizadoras dos recursos ambientais consideradas efetiva ou potencialmente poluidoras ou aquelas que, sob qualquer forma, possam causar degradação ambiental.

Outros tipos de Licença ambiental foram estabelecidos pelo CONAMA para atividades específicas, em função de suas características ou possibilidade de simplificação de procedimentos, já prevista na Resolução CONAMA nº. 237/97. Dentre elas, as licenças unificadas, concedidas em uma única etapa, que podem ser adotadas em: a) novos empreendimentos destinados à construção de habitações de interesse social; b) sistemas de esgotamento sanitário de pequeno porte; c) projetos 
de assentamentos de Reforma Agrária; d) atividades agroindustriais de pequeno porte e baixo impacto ambiental, abatedouros e estabelecimentos que processem pescados (BRASIL/MMA, 2009, p. 36-37).

Neste capitulo será aprofundado o estudo dos tipos de licenças estabelecido no art. 1ํㅡ. inciso II, da lei ํํ. 6938/81, que perpassam por três etapas do licenciamento ambiental. São as respectivas licenças: Licença Prévia, Licença de instalação e licença de operação, já definidos nos Decreto №. 88351 de 1983 e 99.274 de 1990, tais licenças também são especificadas na resolução CONAMA №. 237 de 1997.

\subsubsection{Licença prévia}

Deve-se solicitar a Licença Prévia na fase inicial do planejamento da atividade, pois este tipo de licença que atestará a viabilidade ambiental do empreendimento aprovará sua localização, concepção e definirá as medidas mitigadoras e compensatórias dos impactos negativos do projeto (NOAL; REIGOTA; BARCELOS, 1998).

Tal licença tem como objetivo definir as condições com as quais o projeto torna-se adequado com a preservação do meio ambiente, este procedimento é um compromisso firmado pelo empreendedor de que seguirá o projeto de acordo com os requisitos determinados pelo órgão ambiental para as atividades consideradas efetiva ou potencialmente causadoras de significativa degradação ambiental (TEIXEIRA, 2003).

Porém a concessão da Licença Prévia dependerá de aprovação de estudo prévia de impacto ambiental e respectivo relatório de impacto sobre o meio ambiente (IBAMA, 2002).

A Licença prévia possui extraordinária importância no atendimento ao princípio da prevenção. Esse princípio se delineia quando, diante da ineficácia da impossibilidade de se refazer uma situação anterior idêntica, a ação preventiva. Nesse conceito se encaixam os danos ambientais, cujo impacto negativo muitas vezes é irreversível e irreparável (BAPTISTA; LIMA, 1998). 
Durante o processo de obtenção da Licença Prévia, são analisados diversos fatores que definirão a viabilidade ou não do empreendimento que se pleiteiam, tais como: Levantamento dos impactos ambientais e sociais prováveis do empreendimento; avaliação da intensidade e a abrangência de tais impactos; formulação das medidas que, uma vez implementadas, serão capazes de eliminar ou dirimi os impactos; serão ouvidos os órgãos ambientais das esferas competentes; também serão ouvidos órgãos e entidades setoriais, em cuja área de atuação se situa o empreendimento (OLIVEIRA, 1997).

Outros pontos importantes a serem levantados é que será discutido com a comunidade, caso haja audiência pública, os impactos ambientais e respectivas medidas mitigadoras e compensatórias; e, por fim, deve ser tomada a decisão a respeito da viabilidade ambiental do empreendimento, levando-se em conta sua localização e seus prováveis impactos, em confronto com as medidas mitigadoras dos impactos ambientais e sociais (OLIVEIRA, 1997).

O prazo de validade da Licença Prévia deverá ser, no mínimo, igual ao estabelecido pelo cronograma de elaboração dos planos, programas e projetos relativos ao empreendimento ou atividade, ou seja, ao tempo necessário para a realização do planejamento, não podendo ser superior a cinco anos (OLIVEIRA, 1997).

\subsubsection{Licença de instalação}

Logo após a aquisição da Licença Prévia, inicia-se o detalhamento do projeto de construção do empreendimento, incluindo nesse as medidas de controle ambiental determinadas. Antes de iniciarem-se as obras, deverá ser solicitada a Licença de Instalação junto ao órgão ambiental, que verificará se o projeto é adequado com o meio ambiente afetado. Tal licença dá validade à estratégia proposta para o trato das questões ambientais durante a fase de construção (BRASIL, Lei n. ${ }^{\circ}$ 6.938/81).

Ao conceder a Licença de Instalação, o órgão gestor de meio ambiente terá que tomar algumas atitudes, como a autorização para que o empreendedor possa dar iniciar as obras; Estão de acordo com as especificações constantes dos 
planos, programas e projetos ambientais, seus detalhamentos e respectivos cronogramas de implantação; verificar 0 atendimento das condicionantes determinadas na Licença prévia; estabelecer medidas de controle ambiental, com vistas a garantir que a fase de implantação do empreendimento obedecerá aos padrões de qualidade ambiental estabelecidos em lei ou regulamentos; determinar as condicionantes da Licença de instalação como, medidas mitigadoras ou compensatórias (OLIVEIRA, 1997).

O órgão ambiental deve realizar a fiscalização das condicionantes determinadas na concessão da licença. O acompanhamento é feito ao longo do processo de instalação e será determinado conforme cada empreendimento. $O$ prazo de validade da Licença de Instalação será, no mínimo, igual ao estabelecido pelo cronograma de instalação do empreendimento ou atividade, não podendo ser superior a seis anos (BAPTISTA; LIMA, 1998).

\subsubsection{Licença de operação}

É a Lei federal 6.938/81 que delimita regionalmente a atividade, de acordo com cada Estado. Tal Lei institui a Política Nacional de Meio Ambiente. É importante ressaltar que a Resolução CONAMA 237/97 determina que o licenciamento deva ser solicitado em uma única esfera de ação. Entretanto, o licenciamento ambiental exige as manifestações da cidade, representado pelas Secretarias Municipais de Meio Ambiente (BRASIL, Resolução CONAMA, 1997).

A Licença Ambiental é o documento com prazo de validade definido, em que o órgão ambiental estabelece regras, condições, restrições e medidas de controle ambiental a serem seguidas por sua empresa. Entre as principais características avaliadas no processo podemos ressaltar: O potencial de geração de líquidos poluentes (despejos e efluentes), resíduos sólidos, emissões atmosféricas, ruídos e o potencial de riscos de explosões e de incêndios. Ao receber a Licença Ambiental, o empreendedor assume os compromissos para a manutenção da qualidade ambiental do local em que se instala (FINK; ALONSO JÚNIOR; DAWALIBI, 2004). 
A Licença de Operação autoriza o funcionamento do empreendimento. Esta deve ser requerida quando a empresa estiver edificada e após a verificação da eficácia das medidas de controle ambiental estabelecidas nas condicionantes das licenças anteriores. Nas restrições da LO, estão determinados os métodos de controle e as condições de operação (MACHADO, 2005).

\subsubsection{Procedimentos para a obtenção da licença ambiental}

A Resolução CONAMA n‥ 237/97 detalhou os procedimentos para o licenciamento ambiental e alterou alguns dispositivos definidos no Decreto ํ․ 88351 de 1983, o qual determina que para aquisição do licenciamento ambiental o interessado deva dirigir sua solicitação ao órgão ambiental competente para a emissão do documento. Sendo que o órgão ambiental competente poderá estabelecer prazos de análise diferenciados para cada modalidade de licença, em função das peculiaridades da atividade ou empreendimento, bem como para a formulação de exigências complementares, desde que observado o prazo máximo de seis meses a contar do ato de protocolar o requerimento até seu deferimento ou indeferimento (BRASIL, 1997).

O Procedimento para a obtenção da Licença Ambiental deve obedecer algumas etapas que são a identificação do órgão ambiental competente para licenciar, aquisição da Licença Prévia, elaboração do projeto básico, aquisição da Licença de Instalação, aquisição da Licença de Operação e por fim a regularização de empreendimento não licenciado (SILVA FILHO, 1997).

A renovação da Licença de Operação deverá ser solicitada pelo empreendedor com antecedência mínima de cento e vinte dias do prazo de sua expiração. O pedido de renovação deverá ser publicado no jornal oficial do estado e em um periódico regional ou local de grande circulação (OLIVEIRA, 1997).

Caso o órgão ambiental não conclua a análise nesse prazo, a licença ficará automaticamente renovada até sua manifestação definitiva. Na renovação da Licença de Operação, é facultado ao órgão ambiental, mediante justificativa, aumentar ou reduzir seu prazo de validade, mantendo os limites mínimo e máximo 
de quatro e dez anos. Porém, esta decisão será tomada com base na avaliação do desempenho ambiental da atividade no período anterior (MINISTÉRIO DO MEIO AMBIENTE-MMA, 2009).

É mister frisar que a Licença de Operação se diferencia das demais supracitadas por possuir três características básicas, a saber: A primeira é porque tal licença é concedida após a verificação, pelo órgão ambiental, do efetivo cumprimento das condicionantes estabelecidas nas licenças anteriores (prévia e de instalação); a segunda é por que contém as medidas de controle ambiental (padrões ambientais) que servirão de limite para o funcionamento do empreendimento ou atividade; e a terceira e ultima característica é a de especifica as condicionantes determinadas para a operação do empreendimento, cujo cumprimento é obrigatório, sob pena de suspensão ou cancelamento da operação (IBAMA, 2002).

\subsection{Normas e padrões de qualidade de água na lavagem de veículos}

\subsubsection{Reúso e a reciclagem da água}

A água é a principal matéria prima na atividade de lavagem de veículos, seja na casa dos proprietários, seja de forma sistematizada, em empreendimentos prestadores de serviços, foco da pesquisa. Diante de um uso tão pouco nobre, alternativas de gestão desse insumo invariavelmente surgem. O reúso apresenta-se, nesse sentido, como instrumento de gestão possível. Mancuso (1992) entende, nesse sentido, que a adoção do reúso de água depende do tipo de uso. O tratamento de água, por conseguinte, deve ser visto como meio de purificar a água de qualquer grau de impureza para um grau de pureza adequado ao uso pretendido, predominando, portando a importância de selecionar e combinar, competentemente, os diversos processos unitários que sejam adequados (ARREMÕES apud MANCUSO, 1992).

O porte de investimentos, é importante ressaltar, na criação da infraestrutura de redes duplas de distribuição está sujeito ao uso que vai ser dado à 
água. O planejamento de um sistema como este deve integrar tanto os aspectos do tratamento, como a demanda de água necessária.

Segundo Braile e Cavalcanti (1979), o projeto de um sistema de produção de reúso de água, deve incluir análises como a avaliação do tratamento do esgoto e das disposições finais necessárias aos resíduos produzidos, avaliação do suprimento e demanda de água, avaliação dos benefícios ao suprimento de água baseados no potencial do reúso de água, análise do mercado para o reúso de água, isto é, determinação das possíveis categorias de reúso de água e pesquisa dos possíveis clientes da água para o reúso na região, análises técnicas e econômicas das alternativas encontradas e a implementação do plano com a análise financeira.

É de fundamental importância destacar que a principal diferença entre o conceito de reúso e reciclagem da água é que, enquanto no primeiro caso o efluente a ser reutilizado é o esgoto sanitário, o efluente a ser reciclado é o despejo gerado num determinado processo, o qual vai ser tratado e reaproveitado num mesmo espaço físico, não sendo descartado numa rede coletora de esgotos. Este espaço físico pode ser uma empresa, um posto de combustível, um edifício comercial, um condomínio e outros (CENTURIONE FILHO, 2002).

É importante exemplificar trata-se de um sistema de reciclagem o qual tem a possibilidade de operar com água contendo valores limitados de SST (Sólidos em Suspensão Total) nos chuveiros e na selagem das bombas. Porém $70 \%$ da água residuária seria tratada com FAD Flotação por Ar Dissolvido) e os outros 30\% seriam tratadas com micro filtração, retornando aos chuveiros de limpeza dos feltros com concentração de SST inferiores a 10 mg/L (TEIXEIRA, 2003).

A reciclagem de água diminui o descarte na rede coletora de esgotos e possui diversas peculiaridades, entre estas, pode-se citar as concentrações maiores de certos poluentes e a tendência a aumentá-las à medida que a água recircular, muitas vezes exigindo tratamentos específicos. Como esta recirculação altera a qualidade da água, devem-se considerar fatores como a elevação de temperatura, nutrientes, $\mathrm{pH}$, sólidos em suspensão, cargas orgânicas, metais pesados e tóxicos (TEIXEIRA, 2003).

No entanto, a reciclagem da água apresenta vantagens como a diminuição da carga de poluentes no local de lançamento, a economia de água potável sem a necessidade de investimentos em redes duplas de distribuição. São 
inúmeros os exemplos de reciclagem da água em fábricas, sistemas de resfriamento, fazendas, refinarias, lavanderias industriais, lavagem de veículos e outros (TEIXEIRA, 2003).

\subsubsection{Tipos de reciclagem de água}

O Brasil é um país privilegiado em relação à quantidade de água. Ele possui $13,7 \%$ de água doce do planeta, sendo que $7 \%$ encontram-se na região da bacia hidrográfica do rio Paraná, que inclui o rio Tietê, que está situado no Estado de São Paulo que possui $1,6 \%$ de água doce em sua extensão. E $70 \%$ na Bacia Amazônica, sendo que o volume de água do rio Amazonas é o maior do globo, sendo considerado um rio essencial para o planeta. $O$ restante está situado no Nordeste e Centro-Oeste, no rio São Francisco, mas, porém devido à super população, situadas nas grandes cidades o Brasil vem sofrendo problemas de escassez, isso já atinge os principais rios e represas das grandes cidades (TEIXEIRA, 2003).

No entanto, Mancuso (1992) lembra que há países que enfrentam aguda falta de água, como muitos do Oriente Médio (nove entre dez desses países vivem em condições de escassez). Mancuso (1992) afirma ainda que pelo menos 10 por cento de toda a água utilizada no mundo vai para fins urbanos diversos, que não a agricultura, ou seja, não tem há liberação imediato para reuso.

Em relação à reciclagem, esta pode ser classificada nas seguintes categorias: Reciclagem restrita, que é a que permite uma recirculação de cerca de 50 a $80 \%$ dos efluentes gerados, dependendo do tipo de tratamento empregado. Em geral, utiliza-se um sistema de grade amento para a retenção de sólidos grosseiros e, em alguns casos, processos oxidativos para controle de odores e limitação de crescimento de microrganismos (BRASIL/MMA, 2009).

A segunda classificação é a Reciclagem Ampla, a qual permite uma recirculação de 80 a $95 \%$ dos efluentes gerados, por meio de técnicas de tratamento mais eficientes como aeração, coagulação química, filtração, flotação e 
ozonizarão, visando à eliminação de odores, sólidos grosseiros e suspensos, óleos e graxas e alguns compostos orgânicos (CUNHA, 2004).

A terceira e ultima é a Reciclagem Total (Fechamento do circuito): objetiva a recirculação total (100\%) dos efluentes gerados. Para isso, o emprego de tecnologias de tratamento sofisticadas se torna necessário, como por exemplo, a osmose reversa. Sua implantação requer uma análise criteriosa da relação custo/ benefício (CUNHA, 2004).

\subsubsection{Normas para o reuso de água}

O reuso de água foi realizado por muitos anos sem seguir qualquer norma nacional ou internacional. Nos anos 90 , alguns estados americanos adotaram uma série de padrões e a Organização Mundial de Saúde-OMS, publicou normas para o reúso da água na agricultura, em 1992, a Agência de Proteção Ambiental dos Estados Unidos publicou uma série de normas para o reúso de água (CROOK; SURAMPALLI, 1996).

Segundo Crook e Surampalli (1996), estes padrões de reúso são direcionados principalmente à proteção da saúde, pois a presença de elementos químicos tóxicos e de microrganismos patogênicos cria um potencial de efeitos adversos em locais onde há riscos de contato, inalação ou ingestão. Como não há uma regulamentação federal nos Estados Unidos, a responsabilidade cabe às agências de cada estado. Os autores comparam diferentes critérios adotados em diversos estados e elaboram um resumo sobre os itens principais destas normas, como proteção à saúde, fiscalização, experiência passada em reúso, possibilidades técnicas e econômicas.

As agências estaduais americanas regulamentam padrões para a qualidade da água tratada e o tratamento mínimo necessário. O tratamento se torna mais sofisticado na medida em que o nível de exposição humana à água reutilizada alentasse. (MAGALHÃES, 2005)

No caso do Brasil, tecnologias mais sofisticadas para o reúso de água, como as apresentadas no esquema anterior, não seriam viáveis. A solução para o 
país seria procurar obter simplicidade e eficiência nos tratamentos e ao mesmo tempo minimizar os riscos à saúde humana.

Nota-se que no Brasil não há regulamentações específicas para o processo de reúso de água. Mesmo assim, o governo federal já iniciou processos de gestão para estabelecer bases políticas, legais e institucionais para o reuso. (MORELLI, 2005)

A reutilização de água pode ser direta ou indireta, decorrentes de ações planejadas ou não (CETESB, 2010):

O reúso indireto não planejado da água ocorre quando a água, utilizada em alguma atividade humana, é descarregada no meio ambiente e novamente utilizada a jusante, em sua forma diluída, de maneira não intencional e não controlada. Caminhando até o ponto de captação para o novo usuário, a mesma está sujeita às ações naturais do ciclo hidrológico (diluição, autodepuração). (CETESB, 2010)

Mancuso (1992) define que o reúso da água exige o conhecimento prévio das características físicas, químicas e biológicas das águas residuária ou poluídas, de modo a adequar seu tratamento à obtenção da qualidade baseados em critérios recomendados em países que possuem tais normas.

\subsection{Efluentes na lavagem de veículos}

\subsubsection{Características de efluentes gerados na lavagem de veículos}

O efluente gerado pela atividade de limpeza de automóveis pode conter quantidades significativas de óleos e graxas, sólidos em suspensão, metais pesados, surfactantes e substâncias orgânicas. (TEIXEIRA, 2003) ainda revela que pode, em adição, conter fluído hidráulico e óleo proveniente do motor, constituindo assim uma fonte significativa de (Demanda Química de Oxigênio) - DQO. (TEIXEIRA, 2003). Jonsson e Jonsson (apud TEIXEIRA, 2003) em sua investigação sobre a influência dos diversos tipos de desengraxantes utilizados em lavagem de 
veículos verificaram que a retenção de diversos produtos utilizados apresentaram grades variações de retenção.

De acordo com Teixeira (2003), o impacto ambiental da lavagem de veículos atraiu muita atenção na Suécia. Referindo-se a este efluente como um dos que apresenta mais intensiva atividade química, a Organização Nacional de Fazendeiros Sueca solicitou uma total limitação ao lançamento desse efluente em coletores que o conduzissem a estações de esgoto municipais como requisito para 0 seu reúso desse na agricultura. As autoridades ambientais estabelecem que os lavadores de veículos devam ser equipados com unidades que promovam a separação e retenção do óleo e do lodo antes do lançamento.

A US.EPA (U.S. Environmental Protection Agency) (1999) recomenda que o efluente deva ser descartado no sistema de esgotos. Quando isso não é possível, deve-se reciclar o máximo de água utilizando filtros, separadores de água e óleo e outras tecnologias apropriadas. A preocupação com os poluentes deste despejo, os quais causam impacto nas águas subterrâneas, é crescente em várias regiões dos Estados Unidos.

Por esta razão, vários estados exigem a reciclagem da água de lavagem de veículos e algumas regulamentações chegam a exigir $100 \%$ de reciclagem, ou seja, o fechamento do circuito.

Pavanelli (2001), cita formulações de agentes desengraxantes para a lavagem de veículos contendo 95 a 99\% de hidrocarbonetos e, por volta de, $3 \%$ de surfactantes que são produtos desengraxantes baseados em derivados de petróleo, além de outras, contendo menor quantidade de hidrocarbonetos (10 a $30 \%$ ), maior proporção de surfactantes (10 a 30\%) e solventes, estas últimas conhecidas como micro emulsões, consideradas menos danosas ao meio ambiente.

As águas residuárias geradas nas operações de lavagens de veículos, segundo a U.S.EPA (1999), constituem-se, em sua grande parte de sabão, água de enxágüe e cera. Destaca que, quando não há enxágüe na parte inferior e no motor dos veículos, as concentrações de agentes desengraxantes, solventes e metais pesados, são muito baixos. Caso contrário, a concentração destes poluentes aumenta consideravelmente.

Ao coletar diversas amostras de efluente de poços localizados em estabelecimentos de lavagem de veículos, a U.S.EPA (1999) concluiu que os 
constituintes inorgânicos mais comuns eram NTK (Nitrogênio Kjeldahl Total), cloretos, sólidos dissolvidos totais e sólidos suspensos totais. Destes, apenas os cloretos e os sólidos dissolvidos totais excederam os níveis máximos permitidos na norma local.

Pesquisas com efluentes de lavagem de veículos foram realizadas na Suécia, com a finalidade de verificar o impacto de alguns metais pesados e sua toxicidade em esgotos sanitários. Foi sugerido que se utilizassem detergentes biodegradáveis para diminuir a carga total de poluentes não removíveis e melhorar a qualidade do lodo. Além disso, foi recomendado um tratamento adicional da água residuárias em separadores de óleo, os quais são unidades utilizadas para a remoção primária de óleos e graxas (TEIXEIRA, 2000).

O efluente é armazenado em uma câmara durante um período que possibilite que gotículas de óleo, com densidade menor que da água, formem uma camada na superfície do líquido. O óleo pode ser removido manualmente ou mecanicamente a adição de produtos químicos não é necessária neste tipo de tratamento.

Centurione Filho (2002) realizou um estudo sobre efluentes de lavagens de veículos, mapeando os poluentes orgânicos na rede de esgoto municipal da cidade de Göteborg, o autor percebeu que a eliminação de poluentes orgânicos em separadores de óleo, foi praticamente nula. $O$ autor supracitado comenta que isto ocorreu pela provável formação de emulsões estáveis; a contribuição dos lavadores de veículos na carga total de surfactantes presentes na rede de esgotos não pode ser negligenciada; a utilização de micro emulsões, recomendadas pelas autoridades suecas por serem menos danosas ao meio ambiente, pode aumentar a carga total de surfactantes e foi observado também que embora este efluente exibisse uma concentração relativamente alta de poluentes orgânicos, a contribuição para a carga total no esgoto doméstico foi muito baixa, com exceção do naftaleno.

\subsubsection{Descrição dos tipos de lavagem de veículos}

A indústria de lavagem de veículos inclui diferentes tipos e operações, cada uma com necessidades e características próprias. Variam quanto ao volume de 
água utilizado, carga de contaminantes e substâncias químicas nos processos de lavagem. Porém tais processos são divididos em três tipos:

O túnel é um tipo de lavagem onde o veículo segue pelo do interior do equipamento em formato de túnel, passando por áreas de lavagem, enxágüe, enceramento e secagem, respectivamente. Dentro da área de lavagem, o detergente diluído em água é aplicado e a sujeira é mecanicamente removida por escovas e/ou jatos de alta pressão. A seguir, o automóvel é enxaguado com água limpa.

Logo após este procedimento a secagem é realizada com jatos de ar. $\mathrm{O}$ efluente é coletado em uma vala localizada abaixo do túnel. Em alguns sistemas, a água de lavagem e de enxágüe são mantidas separadas por uma pequena barreira construída na vala. Nos Estados Unidos, este é o tipo mais comum, onde grande parte dos estabelecimentos recicla a água de lavagem e de enxágüe (TEIXEIRA 2003).

No Brasil, diferentemente do túnel americano, normalmente não ocorrem o enceramento e a secagem. A lavagem de veículos é finalizada com remoção da sujeira removida por escovas, e por jatos de alta pressão (TEIXEIRA, 2003).

Outro tipo de lavagem de veiculo é o "Rollover", onde o automóvel fica parado enquanto a máquina de lavagem passa por ele. O equipamento é dotado de escovas em forma cilíndricas que giram em torno de seu próprio eixo. Normalmente, são três escovas, duas laterais e uma superior. O equipamento realiza movimentos para frente e para trás, cobrindo toda a área lateral e superior do carro. O efluente gerado é coletado numa vala situada abaixo do sistema (TEIXEIRA 2003).

O último tipo de lavagem de veiculo é um dos mais comuns na cidade de Imperatriz-MA, que é a lavagem a jato manual, onde se lava o veículo utilizando uma mangueira com jatos de alta pressão de ar e água e sabão, alternando-os. Em alguns casos a água é coletada numa vala. Esse tipo de empreendimento é também muito comum no Brasil (TEIXEIRA 2003). 


\subsubsection{Benefícios e problemas da reciclagem de efluentes na lavagem de veículos}

A reciclagem de efluentes na lavagem de veículos é de fundamental importância para toda a sociedade, pois quanto mais se recicla este menos se polui o meio ambiente. Porém, o sistema de tratamento a ser implantado para viabilizar a reutilização da água e de efluentes na lavagem de carros deve atender às seguintes premissas: Eliminar os riscos à saúde dos usuários e operadores; evitar danos aos veículos; minimizar a necessidade de diluição dos efluentes tratados, e minimizar, seu lançamento na rede de esgotos, em águas superficiais ou em fossas. Pois se utilizando deste procedimento ocorreram os benefícios de minimização da descarga nos corpos receptores; diminuição da carga de poluentes tóxicos na rede de esgotos e a economia de água e efluentes na lavagem dos automóveis. (MORELLI, 2005)Essa citação não está nas referencias

Fica observado que os principais problemas a serem enfrentados no desenvolvimento de tecnologias para a reciclagem de água de lavagem de veículos será a área ocupada que deve ser compacta, pois, provavelmente, será instalado num local onde já funciona um equipamento de lavagem, sem previsão de espaço para a inclusão do equipamento; a geração de odores deve contemplar a necessidade de controle de odores gerados pela proliferação de microrganismos nas águas armazenadas para a reciclagem e a geração de lodo pois a maioria dos sistemas de tratamento de efluentes gera resíduos e estes deverão ter seu volume minimizado e disposição final adequada (MORELLI, 2005).

Outro ponto que merece destaque é o custo de implantação que deve ser o menor possível, de forma que possa ser competitiva com o custo da água, recuperando-se o investimento em curto prazo a operação e manutenção geralmente atende a requisitos de simplicidade, neste aspecto, é um fator limitante na escolha da tecnologia. Sistemas mais complexos tornam-se inviáveis tanto economicamente, como operacionalmente para os proprietários de postos de combustíveis ou lava - jato (MORELLI, 2005).

A concentração de sólidos dissolvidos à medida que a água recircular pelo sistema de lavagem, alguns poluentes podem se concentrar, por não serem 
totalmente removidos no tratamento e por fim, deve se ater à necessidade de diluição devido o aumento na concentração de certos poluentes, a diluição torna-se necessária para manter a qualidade necessária da água a ser reciclada. Pode ser realizada com água potável ou água da chuva (MORELLI, 2005).

\section{MÉTODOS E TÉCNICAS DE PESQUISA}

\subsection{Tipo e descrição geral da pesquisa}

A metodologia utilizada foi de uma pesquisa exploratória e descritiva que propõe observar e descrever a atividade de lava-jato na cidade de Imperatriz - MA. Segundo Gil (2002), uma pesquisa quali-quantitativa tem por objetivo proporcionar maior familiaridade com o problema a ser investigado. Esse tipo de pesquisa assume em geral as pesquisas bibliográficas e estudos de caso. Foi realizado um estudo de caso que juntamente com a revisão bibliográfica tentou buscar uma resposta para o problema a ser investigado.

\subsection{Caracterização da organização}

O estabelecimento do tipo lava-jato numa cidade de pequeno e médio porte é, em princípio, um local de instalações rústicas, formado, basicamente de um terreno com espaço suficiente para manobra de veículos leves e rampas de acesso para o local de lavagem. Não há, via de regra, diferenciação entre o local onde se cuida da parte burocrática do negócio e a atividade fim, sendo, muitas vezes, o escritório formado tão somente de uma escrivaninha onde há sobrepostos bloco de 
anotação e recibo. Não há, tampouco, local específico para funcionários trocarem de roupa ou fazer qualquer tipo de higienização após os turnos de trabalho.

\subsection{População e amostra}

Foram pesquisados 10 estabelecimentos do tipo lava-jatos da cidade de Imperatriz-MA. Esses 10 estabelecimentos são os registrados na Junta Comercial do Estado do Maranhão - JUCEMA e que estão em funcionamento. A quantidade estudada perquire uma porcentagem de $100 \%$ dos lava-jatos legalizados e em funcionamento da Cidade. Ressalte-se que há em toda a cidade um total de 34 estabelecimentos do tipo lava-jato registrados na Junta Comercial. Destes, entretanto, somente os dez estabelecimentos pesquisados encontram-se em atividade.

\subsection{Instrumentos de pesquisa}

A pesquisa teve como principais fontes as referências bibliográficas e a pesquisa de campo. No que concerne a pesquisa bibliográfica, tornou-se patente a tímida existência de literatura especializada no tema central da pesquisa, ao passo que a vasta quantidade de cartas, normas, leis e resoluções compuseram satisfatoriamente o tema acessório, qual seja o licenciamento ambiental. As fontes utilizadas para a pesquisa consistiram na consulta às leis que regem a matéria, à Constituição Federal, à doutrina e artigos científicos.

Para coleta de dados foi aplicado questionário padrão de 10 (dez) perguntas objetivas aos proprietários dos estabelecimentos.

\subsection{Procedimentos de coleta e de análise de dados}


Foram visitados estabelecimentos em funcionamento e aplicados questionários padronizados de dez questões para os proprietários destes, os quais na presença do entrevistador - os responderam. As entrevistas foram antecipadamente agendadas em datas diferentes no espaço de uma semana e ocorreram dentro dos estabelecimentos visitados.

\section{ANÁLISE E INTERPRETAÇÃO DOS RESULTADOS}

Nesse estudo foram pesquisados 10 estabelecimentos de lava jatos da cidade de Imperatriz-MA. Esses 10 lava-jato são os registrados legalmente na Junta Comercial do Estado do Maranhão - JUCEMA, essa quantidade estudada perquire uma porcentagem de $100 \%$ dos lava jatos legalizados do Cidade. Os dados obtidos foram analisados e demonstrados em gráficos abaixo, através de uma pesquisa de campo de caráter quantitativo.

O gráfico número 1 apresenta a escolaridade dos proprietários dos estabelecimentos. Essa informação é relevante, pois, pode-se inferir que o grau de escolaridade reflete o nível de preocupação com o meio ambiente. Um menor nível de escolaridade, nesse sentido, pode sugerir um menor nível de consciência ambiental

De acordo com a pesquisa em amostra, em face da escolaridade dos indivíduos que trabalham nos Java jatos da Cidade de Imperatriz-MA, verificou-se que quanto à escolaridade foi percebido que $30 \%$ dos entrevistados têm o ensino fundamental e $70 \%$ tem nível médio. 


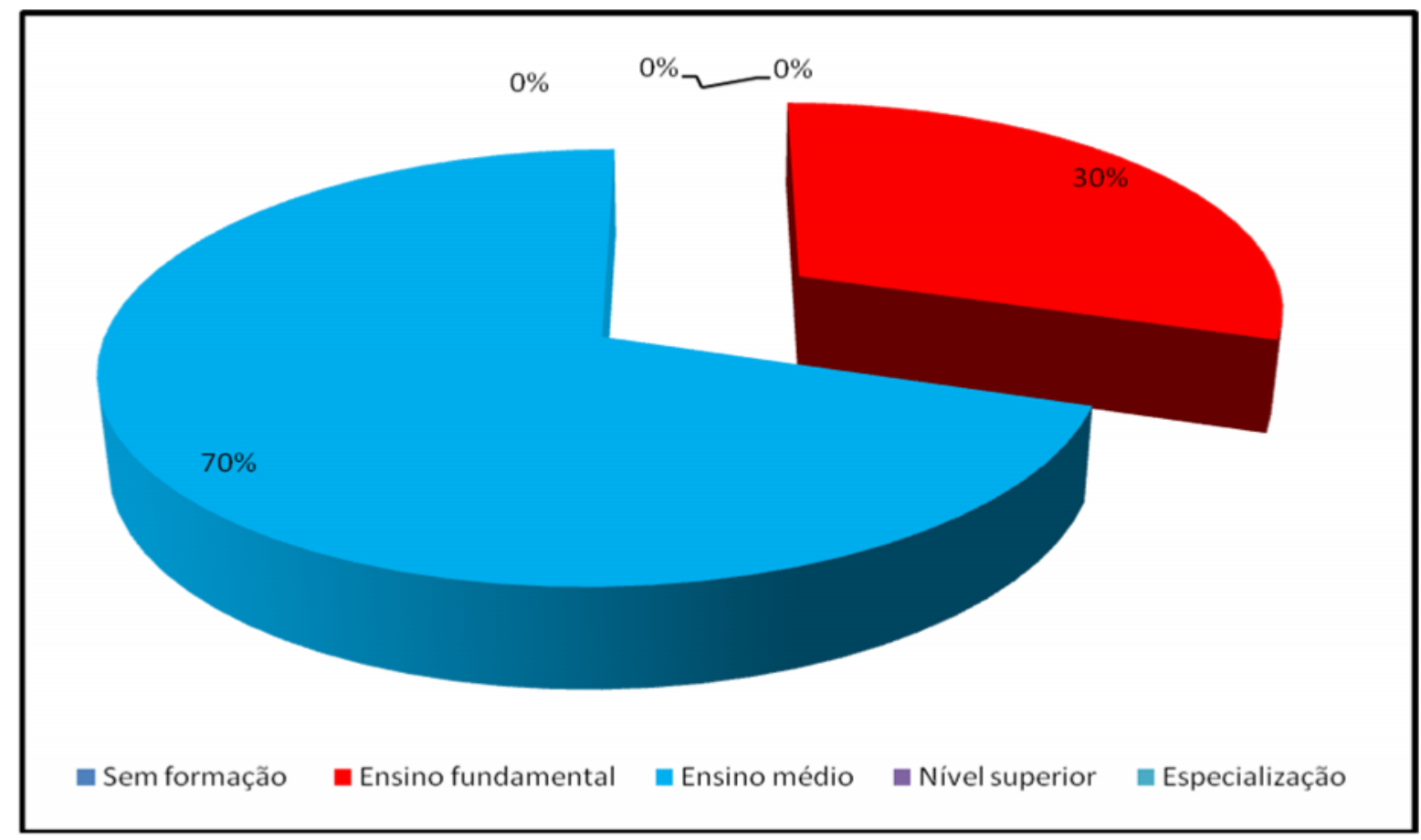

Gráfico 1 - Escolaridade do proprietário.

Fonte: Lava jatos da cidade de Imperatriz-MA, 2010.

O gráfico numero 2 apresenta o tempo de atuação da atividade nos estabelecimentos pesquisados. Observou-se que a pesquisa em amostra em face do tempo de atuação dos indivíduos que trabalham nos Java jatos da Cidade de Imperatriz-MA, verificou-se que $40 \%$ trabalham num período de 2 a 4 anos, 20\% atuam na área num período de 5 a 7 anos, 20\% trabalham num período de 8 a $10 \mathrm{e}$ $20 \%$ trabalham a mais de 10 anos nesta área. Ou seja, 40\% dos entrevistados podem ser considerados como novos empreendimentos. Pequenos empreendedores seduzidos pela relativa facilidade em abrir um Lava-Jato e pelo grande número de veículos nas ruas. 




Gráfico 2 - Qual o tempo de atuação.

Fonte: Lava jatos da cidade de Imperatriz-MA, 2010.

Observou-se que, de acordo com a pesquisa em amostra, em relação aos lava jatos da Cidade de Imperatriz-MA, em face da licença ambiental para exercer suas atividades, verificou-se que $40 \%$ dos lava jatos pesquisados não tem licença ambiental para funcionamento, enquanto que $60 \%$ dos lava jatos possuem licença ambiental para funcionamento.

O terceiro gráfico revela que $60 \%$ dos empreendedores trabalham sem nenhum tipo de licença ambiental. É um dado preocupante que explicita uma situação de negligência por parte de autoridades competentes.

Considerando que a atividade é tida como de pequeno porte, contemplada pela Resolução 237 do Conselho Nacional de Meio Ambiente, a falta desse ajuste de conduta pela maioria dos entrevistados pode caracterizar negligência, tanto por parte dos empreendedores como por parte dos órgãos fiscalizadores. 


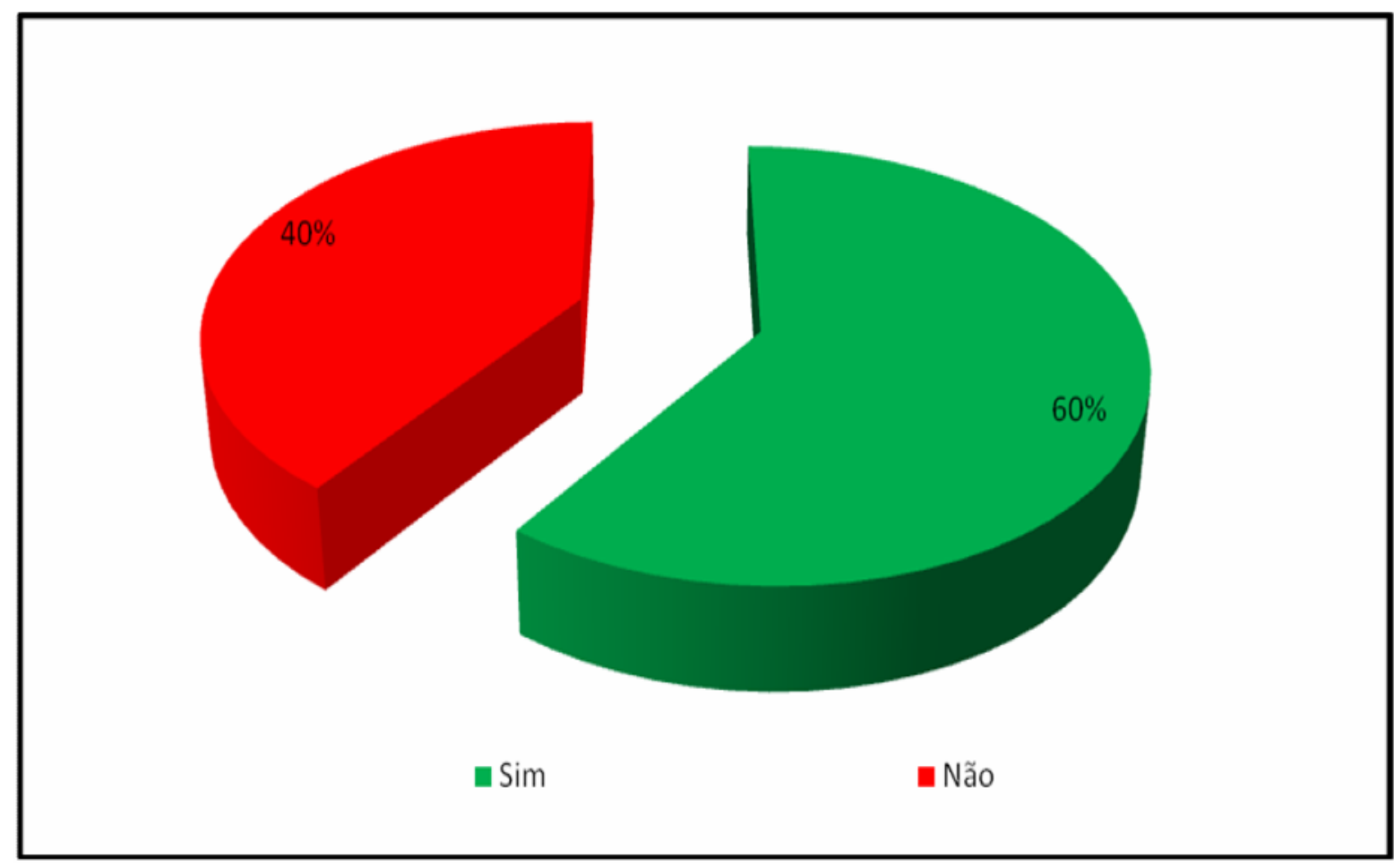

Gráfico 3 - Há Licença ambiental para exercer essa atividade?

Fonte: Lava jatos da cidade de Imperatriz-MA, 2010

De acordo com a pesquisa em amostra em relação ao tratamento de efluente nos lava Jatos, conforme estabelece a Legislação vigente no nosso País, na Cidade de Imperatriz-MA percebeu-se que 50\% dos lava jatos responderam que há tratamento de efluente conforme estabelece a Legislação vigente no nosso País e $50 \%$ dos lava jatos responderam que não há tratamento de efluente conforme estabelece a Legislação vigente. O quarto gráfico desta pesquisa, deixa, novamente, patente a temeridade na qual a atividade pesquisada levanta. $O$ tratamento do efluente gerado por um Lava-Jato é, basicamente, uma caixa coletora (semelhante às caixas de gordura nas residências) que, através da decantação, separa metais pesados, aliviando a água que irá para redes de esgoto. A falta da caixa de gordura significa que grandes quantidades de produtos químicos (resíduos provenientes do motor, óleo e fluídos) serão despejados in natura na rede de esgoto, causando inegável impacto danoso ao meio ambiente. 


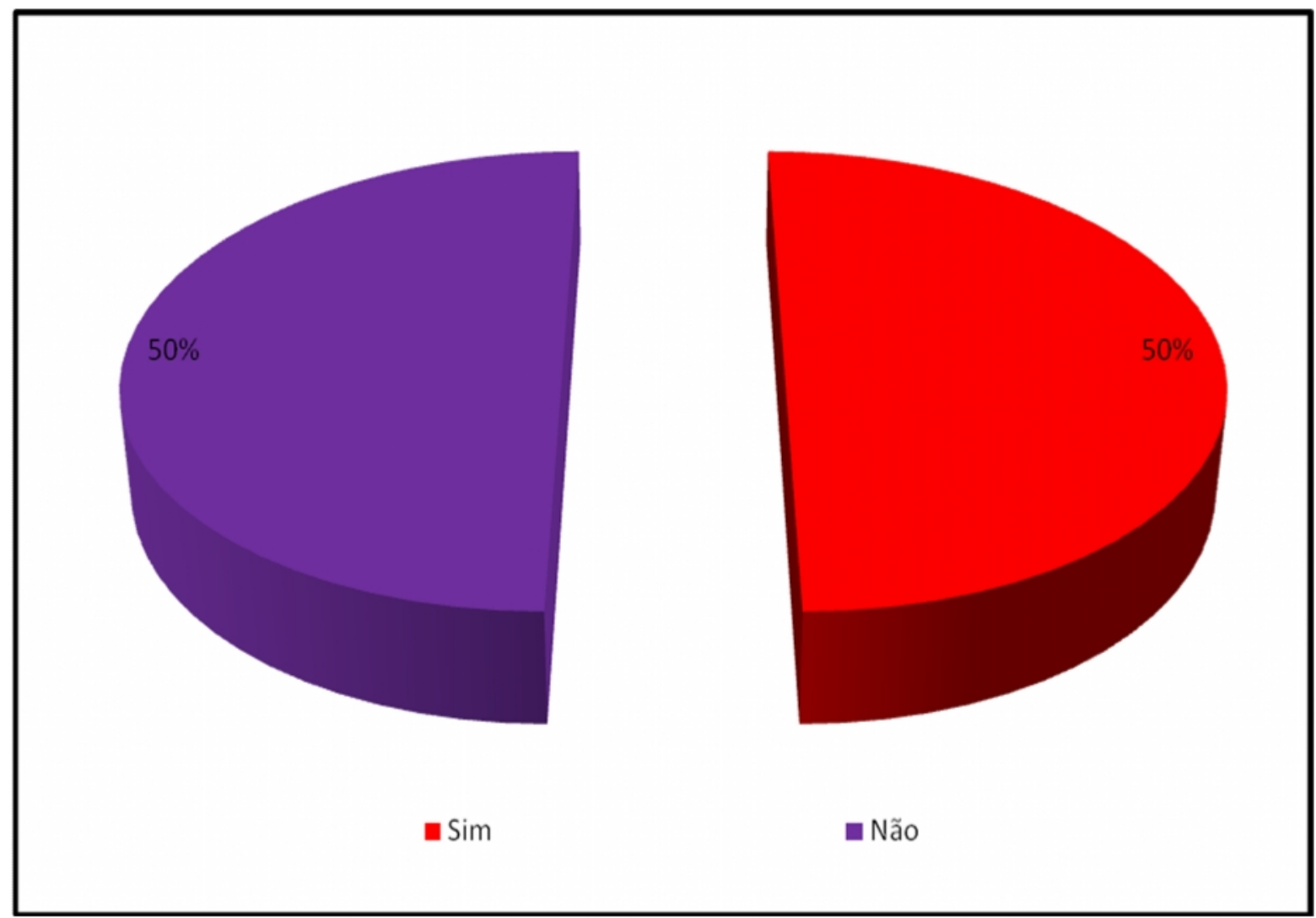

Gráfico 4 - Há tratamento de efluente conforme estabelece a Legislação vigente no nosso País? Fonte: Lava jatos da cidade de Imperatriz-MA, 2010.

Foi observado de acordo com a pesquisa em amostra, em face do controle da quantidade de água utilizada pelos lava jatos da Cidade de ImperatrizMA, percebeu-se que $100 \%$ responderam que existe um controle sobre a quantidade de água utilizada.

É interessante citar que os proprietários de lava jatos do Cidade de Imperatriz-MA, utilizam como base para o controle de água nas lavagens de veículos, reservatórios com uma quantia determinada de água, os quais devem ser usados para a lavagem de um numero especifico de veículos durante cada dia. Nesse sentido, há de se questionar o tipo de controle da quantidade de água na atividade. Não Houve resposta satisfatória no sentido de quantos litros de água são utilizados diariamente e nem quantos litros, em média, são gastos por veículo. Estima-se, entretanto, que pelo menos 450 litros são utilizados para cada veículo. O gráfico 5 representa esse dado. 


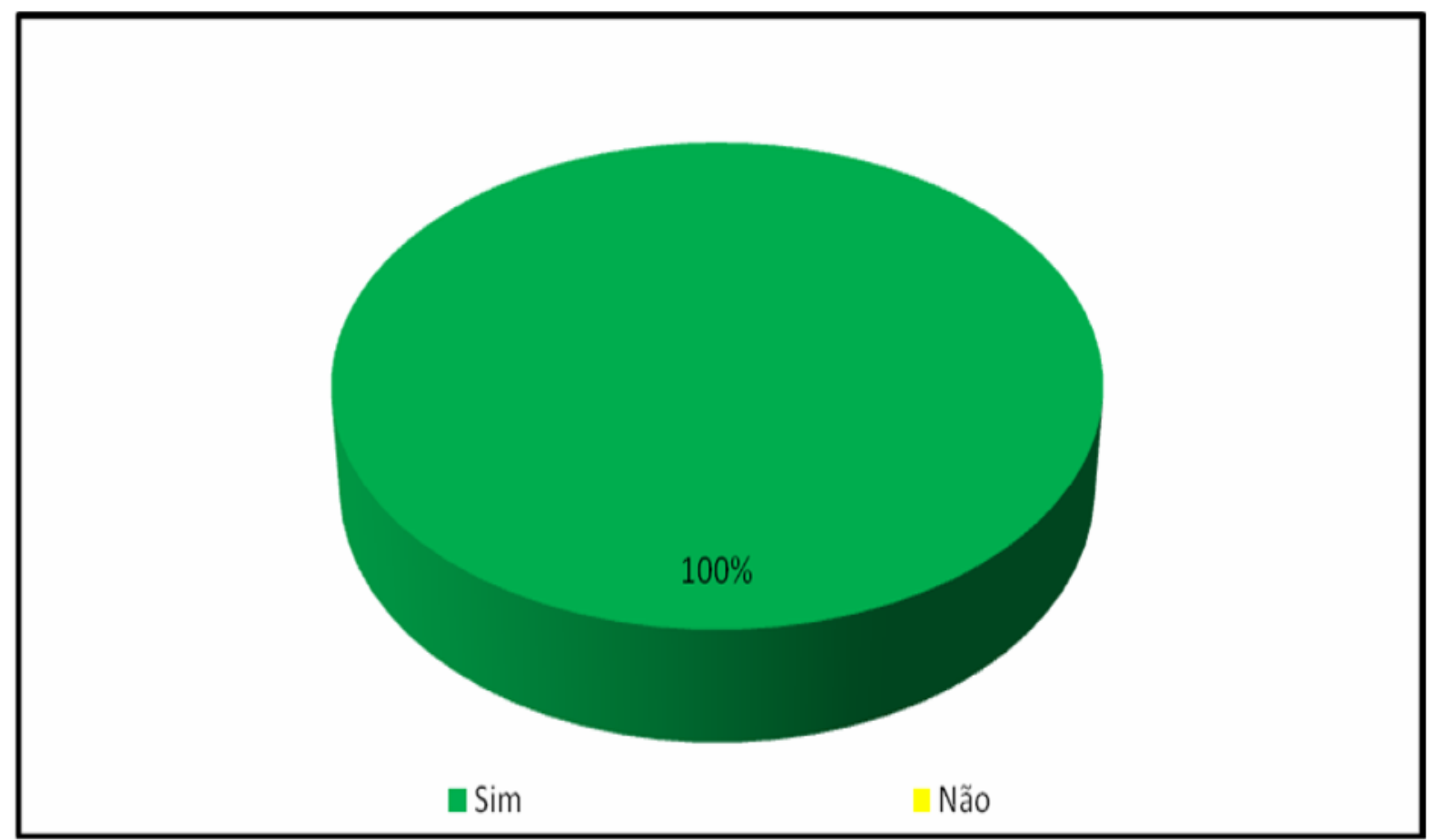

Gráfico 5 - Há controle sobre a quantidade de água utilizada? Fonte: Lava jatos da cidade de Imperatriz-MA, 2010.

Observou-se que de acordo com a pesquisa em amostra em relação aos Java jatos da Cidade de Imperatriz-MA, percebeu-se que $10 \%$ dos lava jatos pesquisados utilizam apenas os produtos recomendados na lavagem de automóveis, como o metasil, que é uma espécie de detergente para limpeza geral, facilmente solúvel em água para shamporizar nas lavagens de veículos, e 90\% responderam que utilizam apenas os produtos que não agridem ao meio ambiente. $O$ metasil é basicamente um desinfetante e, a priori, não se trata de um produto agressor. Entretanto, este produto facilita a liberação dos resíduos incrustados nos motores, agindo, dessa forma, como coadjuvante de um cenário duvidoso. Porém, o gráfico 6 indica que a grande maioria dos estabelecimentos (90\%) não tem qualquer critério na escolha dos produtos. 


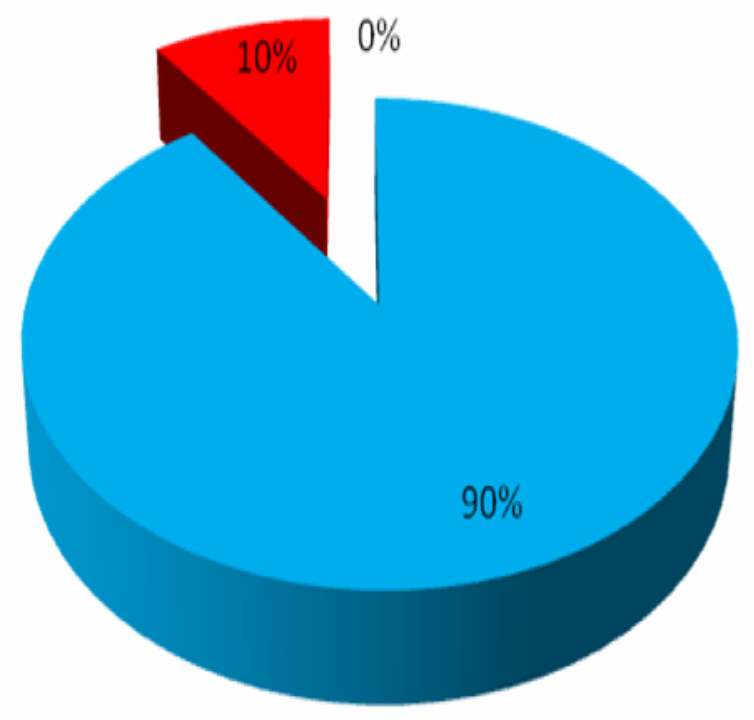

Todos os tipos - Somente os recomendados $\quad$ Somente os que não agridem o meio ambiente

Gráfico 6 - Que produtos são utilizados na lavagem dos automóveis?

Fonte: Lava jatos da cidade de Imperatriz-MA, 2010.

Identificou-se que de acordo com a pesquisa em amostra em relação aos Java jatos da Cidade de Imperatriz-MA, percebeu-se que 20\% dos lava jatos pesquisados respeitam as normas estabelecidas pela legislação ambiental referente ao funcionamento dos lava jatos. E $80 \%$ responderam que às vezes respeitam as normas estabelecidas pela legislação ambiental referente ao funcionamento dos lava jatos. O gráfico 7 explicita um dado altamente preocupante. $80 \%$ dos entrevistados afirmam que só às vezes respeita normas ambientais. Num cenário onde a informalidade já figura como alarmante, estabelecimentos formais, era de esperar, deveriam manter seu funcionamento dentro do mínimo exigido dos padrões legais. 


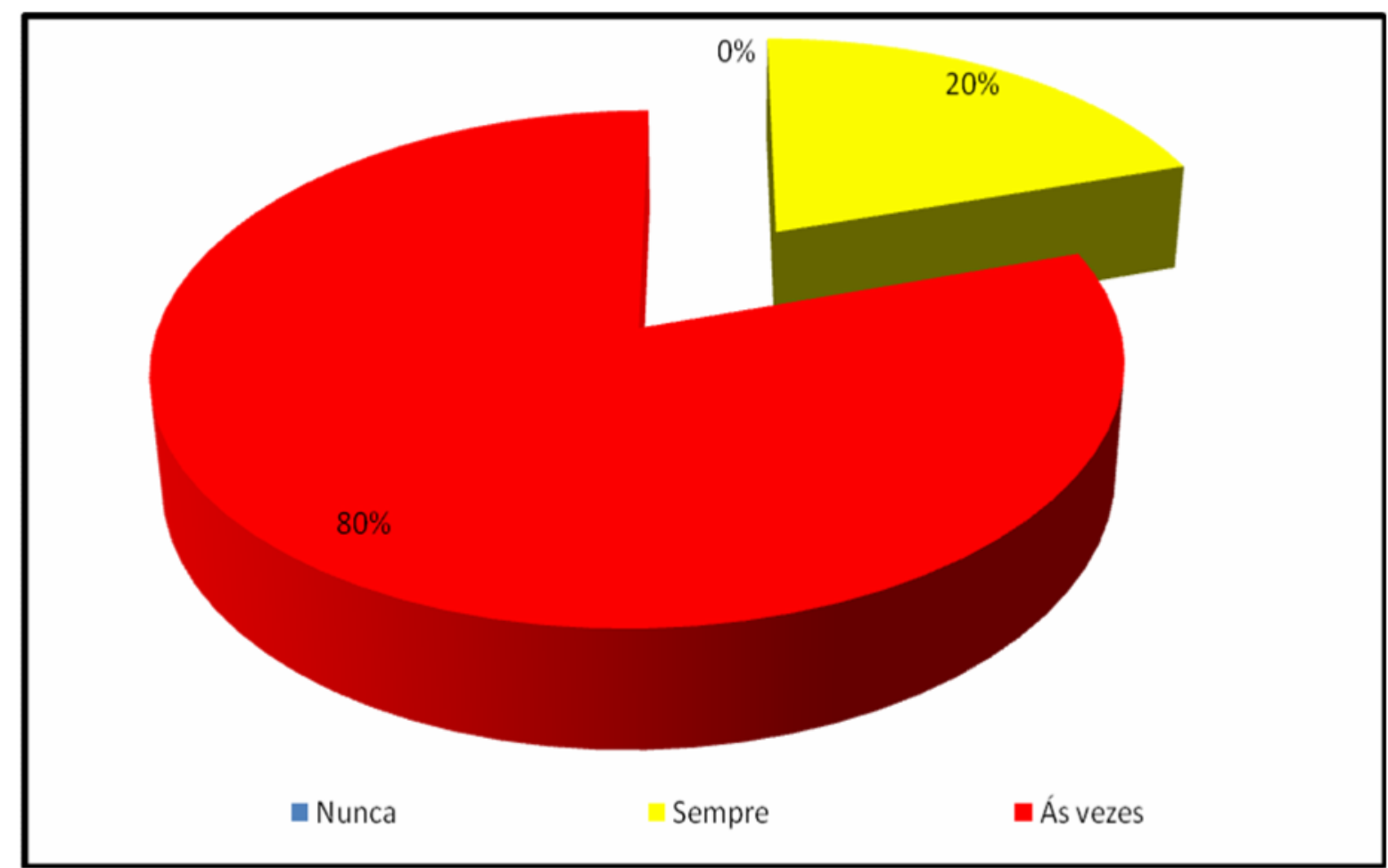

Gráfico 7 - Você respeita as normas estabelecidas pela legislação ambiental referente ao funcionamento dos lava jatos?

Fonte: Lava jatos da cidade de Imperatriz-MA, 2010.

Observou-se que de acordo com a pesquisa em amostra em relação aos Java jatos da Cidade de Imperatriz-MA, foi identificado que 20\% dos funcionários que trabalham nos lava-jato de Imperatriz-MA usam equipamentos de proteção individual - EPI's quando estão no exercício da sua função, 30\% responderam que as vezes usam equipamentos de proteção individual - EPI's quando estão no exercício da sua função e $50 \%$ não usam equipamentos de proteção individual EPI's quando estão no exercício da sua função. A relevância deste gráfico está no fato de a pesquisa ter revelado aspecto socioambiental preocupante, já que metade dos entrevistados não utilizam Equipamento de Proteção Individual - EPI. Muito tem se falado sobre adequação das empresas a normas trabalhistas. Micro e pequenas empresas não estão imunes a tais normas, fazendo-se necessário que também este 
quesito entre em pauta no controle desta atividade. Este último gráfico representa o que a pesquisa acabou por revelar em termos de responsabilidade socioambiental.

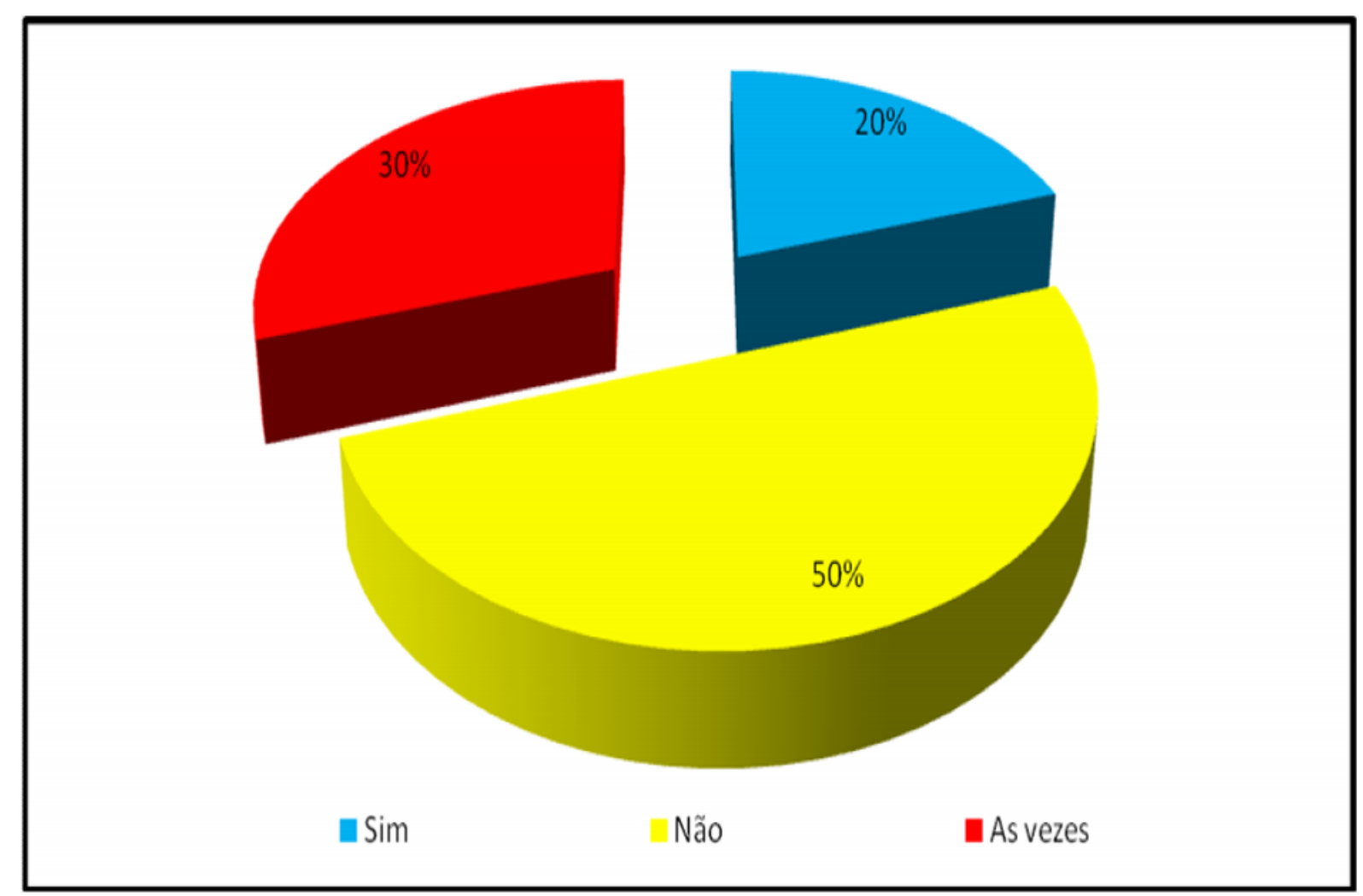

Gráfico 8 - Os funcionários usam equipamentos de proteção individual - EPI's quando estão no exercício da sua função?

Fonte: Lava jatos da cidade de Imperatriz-MA, 2010.

\section{CONSIDERAÇÕES FINAIS}

A pesquisa confirmou a transformação social que ocorreu entre 0 antigo proprietário de veículo que, aos domingos, lavava seu meio de transporte na garagem ou porta de casa para aquele apressado motorista que terceiriza esse serviço para estabelecimentos especializados em lavagem de carros. A busca pelos serviços prestados pelos lava-jatos, nesse sentido, pode ser considerada essencial pelos consumidores. Fatores como aumento do poder aquisitivo e facilidade na 
obtenção de crédito explicam a multiplicação de carros nas ruas, o que, por conseqüência, faz com que haja, proporcionalmente, uma locupletação de prestadores desse tipo de serviço.

Este mercado caracteriza-se por apresentar uma concorrência que está basicamente voltada ao preço. Diante disso, o futuro empreendedor deverá ter em mente a importância de se prestar um serviço de qualidade aliado ao preço e compatível com a legislação ambiental.

O novo empresário deve procurar a prefeitura da cidade, que é o órgão competente, para licenciar sua atividade empresarial para obter informações quanto às instalações físicas da empresa (com relação à localização), e também o Alvará de e as respectivas licenças de funcionamento.

É fundamental, para sua legalização, o registro na Junta Comercial; registro na Secretária da receita Federal; registro na Secretária da Fazenda; registro na Prefeitura da Cidade; registro no INSS; (Somente quando não tem o CNPJ Pessoa autônoma Receita Federal) registro no Sindicato Patronal. Para que o trabalho se torne mais eficiente, é preciso que tenha um conjunto de pessoas, onde cada um é responsável por determinadas funções na lavagem do veiculo.

Verificou-se, portanto, que há relativa facilidade para empreender na área. Em pequenas e médias cidades a facilidade é mais acentuada e, no caso da cidade sede da pesquisa, a informalidade não é incomum.

Nesse sentido, a atividade - por lidar com matéria prima em ritmo acelerado de escassez, a água - torna-se iminentemente perigosa no que concerne - Meio Ambiente. O fato de somente $60 \%$ dos entrevistados afirmarem que possuem algum tipo de licença ambiental demonstra que a pesquisa alcançou 0 objetivo proposto, qual seja, diagnosticar a situação legal da atividade e a situação do controle exercido pelas atividades competentes. Nesse sentido, cumpre a utilização dos dados obtidos por parte de autoridades visando à aplicação das leis ambientais.

A pesquisa, por outro lado - apesar da resposta afirmativa por parte dos entrevistados sobre o controle da quantidade de água utilizada no processo de lavagem de veículos -, falhou em fornecer um dado importante: o total de litros gastos por veículo lavado, ficando aqui boa sugestão para aquele que deseja adentrar esta seara. 
A água desperdiçada ou poluída constitui crime moral para com o homem, ainda dependente em nível vital desse produto.

Por tudo isso, é igualmente vital que haja rigor na aplicação das leis e da criação de novos e específicos instrumentos de controle e fiscalização da atividade. Nessa linha, não há sentido que uma atividade que seja ao mesmo tempo tão comum e tão prejudicial ao meio ambiente tenha sua fiscalização resumida a um ajuste de conduta ou uma licença que não siga padrões semelhantes a empreendimentos de médio e grande porte.

Ainda conclui-se que, por ser caracteristicamente um empreendimento de fácil capilaridade, o Lava-jato deve ser acompanhado com mais contundência, de forma a preservar-se rios, córregos e nascentes de pequenas e médias cidades.

A pesquisa acabou por revelar, por outro lado, importantes aspectos socioambientais a serem explorados em eventuais pesquisas, como a segurança do trabalhador envolvido na atividade, uma vez que apenas 50\% dos entrevistados afirmaram fazer uso de Equipamentos de Proteção individual para os funcionários.

Ao concluir este trabalho, pode-se perceber que a temática da pesquisa é de bastante relevância, visto que o homem é ser que está inserido no meio ambiente. $O$ direito ambiental, nesse sentido, nos faz perceber através da sua letra que cada vez mais o meio ambiente precisa da proteção do homem para manter o equilíbrio da natureza e a perpetuação de nossa espécie. 


\section{REFERENCIAS}

BAPTISTA, Fernando e LIMA, André- Licenciamento Ambiental e a Resolução CONAMA 237/97. Revista de Direito Ambiental, n.12, 1998.

BARBIERI, J. C. Competitividade internacional e normalização ambiental. Revista de Administração Pública*, Rio de Janeiro, v.32 (1), p.57-71, 1998.

BRASIL. Constituição da Republica Federativa do Brasil. Brasília: Senado Federal, Sub Secretaria de Edições Técnicas 2010.

BRASIL. Lei $n .-06.938$, de 31 de agosto de 1981, Dispõe sobre a Política Nacional do Meio Ambiente, seus fins e mecanismos de formulação e aplicação. Republica Federativa do Brasil, Brasília, DF, 02 set. 1981.

BRASIL. lei ํo 9.605, de 12 de fevereiro de 1998. Dispõe sobre as sanções penais e administrativas derivadas de condutas e atividades lesivas ao meio ambiente, e dá outras providências. Brasília. 1998.

BRAILE, P. M., CAVALCANTI J. G. W. A. Manual de Tratamento de Águas Residuárias Industriais. São Paulo: CETESB, 1979.

CENTURIONE FILHO, P. L. (2002). Desenvolvimento e operação de uma instalação de flotação de bancada para águas de abastecimento. Dissertação (Mestrado), EESC, USP.

COSTANZI, R. N. (2000). Estudo de tratamentos físico-químicos - Flotação por ar dissolvido, sedimentação, microfiltração e ozonização - do efluente de uma fábrica de papel para imprimir visando o reúso de água. Dissertação (Mestrado), EESC, USP.

COSTANZI, R. N. (2000). Estudo de tratamentos físico-químicos - Flotação por ar dissolvido, sedimentação, microfiltração e ozonização - do efluente de uma fábrica de papel para imprimir visando o reúso de água. Dissertação (Mestrado), EESC, USP

CROOK, J., SURAMPALI, R.Y. Water reclamation and reuse criteria in the U.S.. Wat. Sci. Tech, 1996.

DOMBROSKI, S. A. G. (1996). Influência das condições de floculação na eficiência da flotação por ar dissolvido de alta taxa aplicada ao tratamento de água de abastecimento. Dissertação (Mestrado), EESC, USP.

CUNHA, Sandra Baptista; GUERRA, Antônio José Teixeira (Org.). Avaliação e perícia ambiental. 5. ed. Rio de Janeiro: Bertrand Brasil, 2004. 
FERREIRA, Aurélio Buarque de Holanda. Novo Dicionário Aurélio. Rio de Janeiro: Nova Fronteira, 1996.

FINK, Daniel Roberto; ALONSO JUNIOR, Hamilton; DAWALIBI, Marcelo. Aspectos jurídicos do licenciamento ambiental. 3. ed. Rio de Janeiro: Forense Universitária, 2004.

IBAMA. Curso de Gestão Ambiental - Instrumentos Aplicados ao Licenciamento (Apostila). Brasília: 2002.

MANCUSO, P. C. S.. Reúso de Água. Associação Brasileira de Engenharia Sanitária e Ambiental, São Paulo: [s. e.], 1992.

MACHADO, Paulo Affonso Leme. Direito ambiental brasileiro. 13. ed. São Paulo: Malheiros, 2005.

MILARÉ, E. e BENJAMIN, A.H.V. Estudo de Impacto Ambiental - Teoria, Prática e Legislação. São Paulo: Revista dos Tribunais, 1993.

Ministério do Meio Ambiente-MMA. Programa Nacional de Capacitação de gestores ambientais: licenciamento ambiental. Brasília: MMA, 2009.

NOAL, Fernando Oliveira, REIGOTA, Marcos, BARCELOS, Valdo Hermes Lima. Tendências da Educação Ambiental Brasileira. Santa Cruz do Sul - RS: Edunisc, 1998.

OLIVEIRA, Antônio Inagê de Assis. Observações Sobre a Resolução CONAMA no 237/97, que Dispõe Sobre o Licenciamento Ambiental. Mimeo, Conselho Empresarial Brasileiro Para o Desenvolvimento Sustentável, 12 de janeiro de 1997.

PAVANELLI, G. (2001). Eficiência de diferentes tipos de coagulantes na coagulação, floculação e sedimentação de água com cor ou turbidez elevada. São Carlos. Tese (mestrado) - Escola de Engenharia de São Carlos, Universidade de São Paulo.

SALGADO, F.G.A. e PALHARES, M. O uso do Licenciamento Ambiental como recurso Gerencial. In: Ambiente, vol. 7, no 1, 1993.

SILVA FILHO, Derly Barreto e. A processualidade das licenças ambientais como garantia dos administrados. Revista de direito ambiental, Rio de Janeiro, ano 2, p. 81-91, jan./mar. 1997.

TEIXEIRA, Priscila C. (2003). Emprego da filtração por ar dissolvido no tratamento de efluentes de lavagem de veículos visando a reciclagem de água, Dissertação apresentada à Faculdade de Engenharia Civil da Universidade Estadual de Campinas, Campinas - SP. 
Morelli, Eduardo Bronzatti (2005). Reúso de água na lavagem de veículos. Dissertação apresentada à Escola Politécnica da Universidade de São Paulo. São Paulo - SP 


\section{APÊNDICE}


Apêndice A - Questionário de coleta de dados da pesquisa de campo

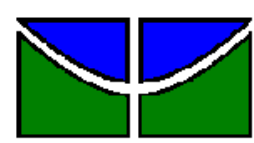

UNIVERSIDADE DE BRASÍLIA

FACULDADE DE ECONOMIA, ADMINISTRAÇÃO, CONTABILIDADE E CIÊNCIAS DA INFORMAÇÃO E DOCUMENTAÇÃO

CURSO DE GRADUAÇÃO EM ADMINISTRAÇÃO A DISTÂNCIA

Caro (a) Entrevistado (a):

O questionário abaixo faz parte de uma pesquisa monográfica cujo o tema é: Licenciamento Ambiental - Estudo de caso sobre a Atividade Lava-Jato na cidade de Imperatriz - MA. Desde já agradeço pela sua colaboração. Obrigado!

QUESTIONARIO PARA COLETA DE DADOS DA PESQUISA DE CAMPO APLICADO AOS GERENTES DOS LAVA JATOS DE IMPERATRIZ-MA

01) Escolaridade do proprietário:
( ) Sem formação
( ) Ensino fundamental
( ) Ensino médio
( ) Nível superior
( ) Especialização

02) Qual o tempo de atuação?
( ) Menos de 1 anos
( ) Entre 2 e 4 anos
( ) Entre 5 e 7 anos
( ) Entre 8 e 10 anos
( ) Mais de 10 anos

03) Há licença ambiental para exercer essa atividade?
( ) $\operatorname{Sim}$
( ) Não 
04) Há tratamento de efluente conforme estabelece a Legislação vigente no nosso País?
( ) $\operatorname{Sim}$
( ) Não

05) Há controle sobre a quantidade de água utilizada?
( ) $\operatorname{Sim}$
( ) Não

06) Que produtos são utilizados na lavagem dos automóveis ?
( ) Todos os tipos
( ) Somente os recomendados
( ) Somente os que não agridem o meio ambiente

07) Você respeita as normas estabelecidas pela legislação ambiental referente ao fucnionamneto dos lava jatos?
( ) Nunca
( ) Às vezes
( ) Sempre

08) Os funcionários usam equipamentos de proteção individual - EPI's quando estão no exercício da sua função?
( ) Sim
( ) Não
( ) Às vezes 